IZA DP No. 7083

Income Inequality and Saving

Francisco Alvarez-Cuadrado

Mayssun El-Attar Vilalta

December 2012

Forschungsinstitut zur Zukunft der Arbeit Institute for the Study of Labor 


\title{
Income Inequality and Saving
}

\author{
Francisco Alvarez-Cuadrado \\ McGill University \\ and CIREQ
}

\author{
Mayssun El-Attar Vilalta \\ McGill University \\ and IZA
}

\section{Discussion Paper No. 7083 \\ December 2012}

\author{
IZA \\ P.O. Box 7240 \\ 53072 Bonn \\ Germany \\ Phone: +49-228-3894-0 \\ Fax: +49-228-3894-180 \\ E-mail: iza@iza.org
}

\begin{abstract}
Any opinions expressed here are those of the author(s) and not those of IZA. Research published in this series may include views on policy, but the institute itself takes no institutional policy positions. The IZA research network is committed to the IZA Guiding Principles of Research Integrity.

The Institute for the Study of Labor (IZA) in Bonn is a local and virtual international research center and a place of communication between science, politics and business. IZA is an independent nonprofit organization supported by Deutsche Post Foundation. The center is associated with the University of Bonn and offers a stimulating research environment through its international network, workshops and conferences, data service, project support, research visits and doctoral program. IZA engages in (i) original and internationally competitive research in all fields of labor economics, (ii) development of policy concepts, and (iii) dissemination of research results and concepts to the interested public.
\end{abstract}

IZA Discussion Papers often represent preliminary work and are circulated to encourage discussion. Citation of such a paper should account for its provisional character. A revised version may be available directly from the author. 
IZA Discussion Paper No. 7083

December 2012

\section{ABSTRACT}

\section{Income Inequality and Saving}

Over the last three decades, average income for the bottom half of the US distribution increased by $8 \%$ while their average saving rate decreased by eight percentage points. Over the same period the US experienced a substantial increase in inequality and a continuous decrease in the aggregate saving rate. We propose an explanation based on interpersonal comparisons consistent with these trends. When households care about their consumption relative to others, individual saving rates decrease with reference income while aggregate saving decreases with income inequality. We provide evidence from the PSID and a panel of OECD countries consistent with these predictions.

JEL Classification: D91, E21, C23

Keywords: relative consumption, income inequality, saving

Corresponding author:

Francisco Alvarez-Cuadrado

Department of Economics

McGill University

855 Sherbrooke St. West

Montreal, Québec H3A 2T7

Canada

E-mail: francisco.alvarez-cuadrado@mcgill.ca 


\section{Introduction}

James Duesenberry, in his seminal work, Income, Saving and the Theory of Consumer Behavior (1949), introduces the relative income hypothesis in an attempt to rationalize the well established differences between cross-sectional and time-series properties of saving rates. On the one hand, a wealth of studies based on 1935-36 and 1941-42 cross-sectional budget surveys present a saving ratio that increases with income. On the other hand, the time series data on savings and income collected by Kuznets (1942) present a trend-less saving ratio. Duesenberry (1949) proposes an individual consumption function that depends not only on current individual income but also on the level of income of the reference group. As a result "for any given relative income distribution, the percentage of income saved by a family will tend to be a unique, invariant, and increasing function of its percentile position in the income distribution. The percentage saved will be independent of the absolute level of income. It follows that the aggregate saving ratio will be independent of the absolute level of income" (Duesenberry 1949, p. 3). Despite its empirical success, see for instance Mayer (1966, 1972), the relative income hypothesis was quickly replaced by the well-known permanent income hypothesis (Modigliani and Brumberg (1954), Friedman (1957)) as the economists' workhorse to understand saving behavior 11 According to this view the cross-sectional correlation between saving rates and income is driven by transitory deviations from permanent income, while in the aggregate, most transitory components cancel out, leading to the close relation between consumption and income observed in time series data. In a recent paper, Dynan, Skinner and Zeldes (2004) resolve this old empirical question. Applying new methods to a variety of saving measures derived from the Panel Study of Income Dynamics (PSID), the Survey of Consumer Finances (SCF), and the Consumer Expenditure Survey (CEX) they find a strong positive relationship between saving rates and lifetime income.

The goal of this paper is twofold. First, we identify interpersonal comparisons as one of the channels behind the documented gradient between saving rates and lifetime income. Second, we explore the impact of income inequality on this gradient. For this purpose, we propose a simple model of interpersonal comparisons. Our overlapping generations economy is populated by heterogeneous households who care about consumption relative to others and derive a "warm-glow" from the bequest they leave to their descendents. Analyzing the saving choices of one generation, we find several testable implications. First, individual saving rates increase

\footnotetext{
${ }^{1}$ One should point out that Friedman's view is more nuanced than the profession seems to believe "... and finally, the evidence that we have cited seems to fit it (the permanent income hypothesis) somewhat better...however, this evidence is by no means sufficient to justify a firm rejection of the relative income hypothesis" (Friedman 1957, p. 169).
} 
with lifetime income. Second, saving rates decrease with the level of income of the reference group and they do so more for poor households. Third, an increase in income inequality leads to an increase in inequality of saving rates. And fourth, once we allow for upward-looking interpersonal comparisons, a mean preserving spread in the distribution of labor income leads to a decrease in the aggregate saving rate.

Using several measures of saving derived from the PSID, we test the first three predictions. We find, in line with Dynan et al. (2004), a strong positive gradient between saving rates and income conditional on life-cycle and demographic characteristics. On average an increase in income of $10 \%$ is associated with an increase in the saving rate that ranges between 0.4 and 0.5 percentage points depending on the measure of saving used. Approximating income of the reference group by average income in the state of residence, we find that, after controlling for household income and other individual characteristics, saving rates decrease in comparison income and do so more for poor households. For instance, our results suggest that a $10 \%$ increase in income of the reference group leads to a decrease in the total saving rate for a household in the 10th income percentile of one fifth of a percentage point. This is a large decrease, particularly if one considers that the average saving rate in the bottom decile is close to zero. When we include a measure of income inequality, we find that those regions or periods with higher income inequality are characterized by a more unequal distribution of saving rates controlling for income. Furthermore, all these results remain robust when we instrument for permanent income using average labor earnings, different measures of consumption, and education. Most importantly, we conduct several exercises to rule out the possibility of reverse causality and provide additional evidence that the impact of inequality on saving rates that we identify is indeed due to interpersonal comparisons and not to other factors.

Finally, we test the last proposition constructing a panel that includes personal saving rates for six developed countries compiled from OECD statistics and measures of inequality from Alvarado, Atkinson, Piketty and Saez (2012). Our sample, although limited in terms of country coverage, spans over 50 years and accounts for roughly $40 \%$ of world GDP. Our results consistently suggest a negative correlation between saving rates and inequality. This correlation persists when we include country fixed effects and other determinants of aggregate saving such as age dependency ratios (Modigliani 1970), GDP growth (Carroll and Weil 1994), or real interest rates (Boskin 1978).

Our empirical methodology is closely related to Dynan et al. (2004). While they focus on documenting and exploring the robustness of the gradient between saving rates and permanent incom $2^{2}$, our paper investigates one of the channels through which changes in permanent income

\footnotetext{
${ }^{2}$ Specifally this gradient does not seem to be caused by life-cycle differences or variation in Social Security
} 
lead to changes in saving rates, interpersonal comparisons, and studies the impact of income inequality on this gradient. In a similar way, our work is related to Altonji and Villanueva (2007) who find that the fraction of every extra dollar of lifetime resources that parents pass to their children through inter vivos transfers or bequests increases with parental income. The results of the empirical literature that tests the impact of the income distribution on aggregate saving are scarce and inconclusive ${ }^{3}$. On the one hand, Blinder (1975) using US time-series data finds that higher income inequality raises aggregate consumption and therefore lowers saving. Although the estimated effects are in general statistically insignificant. On the other hand, Hong (1995) evaluates the effect of the income share of the top quintile on gross domestic saving in a sample of developing and industrial countries. He finds that this share has a positive effect on aggregate saving, suggesting that inequality increases saving. Finally, using data for 11 countries between 1921 and 2002, Leigh and Posso (2009) find no consistent relationship between top income shares and national saving rates. A potential explanation for these mixed results may lie in the use of different measures of saving, most of them derived from the current account identity. In this sense, our measure of aggregate saving, the personal saving rate, draws a clearer picture of the interaction between inequality and aggregate saving 4 .

Our model is closely related to the extensive literature on relative consumption. Abel (1990), Gali (1994), Corneo and Jeanne (1998), Carroll, Overland and Weil (2000), Liu and Turnovsky (2005) and Wendner (2012) are just a few examples. In a context similar to ours, Levine, Frank and Dijk (2010) present a model in which changes in one group's spending shift the frame of reference that defines consumption standards for others just below them in the income scale, giving rise to expenditure cascades. Along these lines, a recent paper by Bertrand and Morse (2012) finds that up to a quarter of the decline in the saving rate over the last three decades could be attributed to these expenditure cascades. Our work also connects with the recent literature on self-reported well-being. Early work by Easterlin (2010, 1995), and Oswald (1997) found differences between the cross-section and time-series properties of happiness data that are quite similar to those reported on savings data more than sixty years ago. Data

replacement rates (Huggett and Ventura 2000), or by a precautionary motive together with uncertain medical expenses (De Nardi, French and Jones (2010), Kopecky and Koreshkova (2010)), or by the presence of dynastic smoothing (Becker and Tomes, 1986) or by the inclusion of high-income entrepreneurs in their sample (Quadrini (1999) and Hurst and Lusardi (2004)).

${ }^{3}$ See Schmidt-Hebbel and Serven (2000) for a review of this literature.

${ }^{4}$ Theoretical models on the relation between saving and inequality focus on household behavior suggesting that the relevant aggregate variable in an empirical analysis should be close to the personal saving rate that we use (see for instance, Deaton (1991), Alesina and Rodrik (1994), and Person and Tabellini (1994)). With the exception of Blinder (1975) previous studies have used measures of saving that include public and corporate saving. 
on self-reported well-being shows that within a country at a given point in time those with higher incomes are, on average, happier. However, average happiness in developed countries has remained relatively constant over time despite sharp increases in per capita GDP. Clark, Frijters and Shields (2008) highlight the importance of accounting for interpersonal comparisons to account for the "Easterlin paradox" 5 . Recent work has tried to estimate the direct impact of interpersonal comparisons on self-reported well-being. Luttmer (2005), Ferrer-i Carbonell (2005) and Dynan and Ravina (2007) find that people's level of happiness depends positively on how well they are doing relative to the average in their geographical area, even after controlling for own income levels. Our model formalizes some of these insights and explores the implications of relativity concerns for saving $\$$.

Finally, Dynan et al. (2004) find, not only a strong positive relationship between saving rates and lifetime income but also evidence suggesting that the marginal propensity to save out of lifetime income is higher for rich households than for poor ones. Figure 2(a) illustrates these results. The rich not only save more as a fraction of their lifetime income but they also save a higher fraction of each additional dollar of income. Other things equal, an increasing marginal propensity to save has at least two direct implications. First, as households become richer their saving rates should increase. So at the individual level, we should find an increase in saving rates as permanent income increases. Second, if we redistribute income from households with a low marginal propensity to save to those with a high marginal propensity to save the aggregate saving rate should increase. So at the aggregate level, we should find that increases in income inequality should be associated with increases in the average saving rate. Using PSID data from 1994 to 2007, figure 2(b) depicts the evolution of average income and the average saving rate for households below the median of the US (lifetime) income distribution. Over this period, their average income increased by $8 \%$ while their average saving rate fell by almost 8 percentage points 7 . Figure 2(c) combines the evolution of the share of income of the top

\footnotetext{
${ }^{5}$ See Stevenson and Wolfers (2008) for a recent reassestment of this paradox.

${ }^{6}$ Our work is also related to the recent debate on the different patterns of income and consumption inequality. Over the thirty years that preceded the Great Recession, the US experienced a sustained increase in income inequality (Katz and Autor (1999); Autor, Katz and Kearney (2008)). Along similar lines Cutler and Katz (1992) document that changes in the distribution of consumption parallel changes in the distribution of income. Slesnick (2001) questions these findings and Krueger and Perri (2006) using CEX data find that despite the surge in income inequality consumption inequality has increased only moderately. Attanasio, Hurst and Pistaferri (2012) focusing on expenditure categories that are measured without error, such as a vehicles owned, or exploiting differences in demand income elasticities across categories to account directly for the non-classical measurement error, that seems to plague most expenditure categories in this dataset, find that consumption inequality has increased by nearly the same amount as income inequality. Although our focus is not on documenting the patterns on saving inequality our findings are informative on the effect of inequality in saving.

${ }^{7} A$ similar pattern has been reported by Bosworth and Anders (2008). These authors show that, once some extreme values are trimmed, average saving by individuals in the lower third of the income distribution has
} 
$5 \%$ of the distribution from the update of Piketty and Saez (2003) with the personal saving rate from the Federal Reserve Economic Data. In the early 80s, personal saving were roughly $10 \%$ of disposable income falling to barely $2 \%$ by 2007 . Over the same period the share of income of the top $5 \%$ increased by more than $50 \%$ from $21 \%$ to $33 \%$. Our model provides a simple explanation, combining all three trends. In the presence of interpersonal comparisons, individual saving depends not only on individual lifetime income but also on the lifetime income of the reference group. As a result and despite the $8 \%$ increase in lifetime income of households below the median, their saving rates have fallen as a consequence of the much faster increases in income for those in the upper tail of the distribution. For instance, average income for the top decile increased by roughly $38 \%$ over the same period. At the aggregate level, and despite of the fact that the model's marginal propensity to save is independent of the level of income, an increase in the share of income received by high-income households induces a reduction in the levels of saving of low-income households that goes beyond this propensity. The reason lies in the increase in consumption of high-income individuals that stimulates envious consumption further depressing saving for low-income individuals. As a result, increases in income inequality are associated with decreases in the aggregate saving rate.

The remaining of the paper is organized as follows. In Section 2 , we set out the basic model and derive its implications for the interaction among saving, income and inequality. In Section 3. we use data from the PSID to test these implications. In Section 4, we extend the model to allow for a upward-looking comparisons and explore its implications for aggregate saving. These implications are tested in Section 5. In Section 6 we offer some concluding remarks, while the Appendices provide additional details on the derivations and results.

\section{Individual Saving and Income Inequality}

Consider an OLG economy where the wages per unit of effective labor, $w_{t}$, and the gross return to saving, $R_{t}$, are exogenously determined $\square^{8}$

Individuals live for two periods, "youth" and "old-age". At the end of their youth, each individual gives birth to a single offspring and therefore the labor force is constant. Each generation consists of a set of agents, indexed by $i$, distributed uniformly along the unit interval with a total population mass of 1 . Our agents are altruistic toward their children, deriving a "warm-glow" from the bequest, $b_{t+1}^{i}$, that they leave to their descendants as in Adreoni (1989)9

fallen over the period 1984-2005.

${ }^{8}$ See Alvarez-Cuadrado and Long (2012) for a similar model with endogenous factor price determination.

${ }^{9}$ There are alternatives to this approach of modelling the motives for intergenerational transfers. Barro 
Individuals within a given generation differ in their endowment of productive labor, $l_{t}^{i}$, and in the bequest they inherit from their parent, $b_{t}^{i}$. Specifically, we assume that their labor productivity is the realization of a stationary i.i.d. random variable with mean $\bar{l}=1$ and standard deviation $\sigma^{l}$. The resulting distribution of wages for period $t$ has mean $\bar{w}_{t}=w_{t}$ and standard deviation $\sigma_{t}^{w}=w_{t} \sigma^{l}$.

Let's focus on the $i$-th individual born in period $t$. When young, he inelastically supplies his labor endowment, earning an income $w_{t}^{i}=l_{t}^{i} w_{t}$ that together with his inherited wealth, $b_{t}^{i}$, is divided between first-period consumption, $c_{t}^{i}$, and saving, $s_{t}^{i}$. His first-period budget constraint is given by,

$$
c_{t}^{i}+s_{t}^{i}=b_{t}^{i}+w_{t}^{i} \equiv y_{t}^{i}
$$

where we denote by $y_{t}^{i}$ his lifetime resources.

In the second period of his life, the individual is retired. His only source of income is the return on the savings he made when young, $R_{t+1} s_{t}^{i}$, which he allocates to second-period consumption, $d_{t+1}^{i}$, and bequests, $b_{t+1}^{i}$,

$$
R s_{t}^{i}=d_{t+1}^{i}+b_{t+1}^{i}
$$

The preferences of an individual born in period $t$ are given by the following life-cycle utility function,

$$
U\left(\hat{c}_{t}^{i}, \hat{d}_{t+1}^{i}, b_{t+1}^{i}\right)=\ln \left(c_{t}^{i}-\gamma \bar{g}_{t}^{i}\right)+\beta\left[\ln \left(d_{t+1}^{i}-\eta \bar{o}_{t+1}^{i}\right)+\mu \ln \left(b_{t+1}^{i}\right)\right]
$$

where $0<\beta<1$ is the subjective discount factor and $\mu>0$ governs the importance of the bequest motive.

Our key behavioural assumption is that the satisfaction derived from consumption does not depend on the absolute level of consumption itself but rather on how it compares to the consumption of some reference group. Following Ljungqvist and Uhlig (200) we adopt an additive specification for relative consumption where, for the moment, $\bar{g}_{t}^{i}=\bar{c}_{t}=\int_{0}^{1} c_{t}^{j} d j$ and $\bar{o}_{t+1}^{i}=\bar{d}_{t+1}=\int_{0}^{1} d_{t+1}^{j} d j$ are the reference consumption levels when young and old respectively for any household born at time $t$. The importance of positional concerns when young and old is

(1974) considers pure altruism, while in Abel (1985) accidental bequests arise from market incompleteness, and Bernheim, Schleifer and Summers (1985) propose a bequest-as-exchange model. The empirical evidence for the reasons for inter-generational transfers is mixed. Nonetheless, the evidence reviewed by Arrondel, Parelman and Pestieau (1994) and Davies and Shorrocks (1999) suggests that an important fraction of the observed inheritances seems to reflect some kind of impure altruism close to the warm glow approach that we adopt. 
given $0<\gamma<1$ and $0<\eta<1$ respectively ${ }^{10}$. Concerning the relative magnitude of $\gamma$ to $\eta$, one may consider the work of development psychologists and sociologists (Coleman (1961), Simmons and Blyth (1987), Corsaro and Eder (1990)) which suggests that interpersonal comparisons and peer effects are more pronounced early in life. In the "first-period" of life, people work, find partners, and raise children, being exposed to and therefore influenced by a wide variety of social networks. More direct evidence comes from Charles, Hurst and Roussanov (2009) who find that differences in visible consumption disappear when they restrict their sample to older households, suggesting that the relative importance of interpersonal comparisons decreases with age. In line with this evidence, we assume the following relationship between the degrees of envy in both periods of life, $\eta=\xi \gamma$, where $0<\xi \leq 1$.

An important assumption concerns the non-positionality of bequests. Their limited observability and their concentration in the upper tail of the wealth distribution suggest that bequests possess important non-positional features. Along these lines, Moav and Neeman (2010) present a signalling game of status where agents derive utility from consumption, status, and a bequest, which they model as non-observable. The non-observability of bequests in a signalling game is equivalent to its non-positionality in a model of relative consumption. Heffetz (2011) conducts a survey on the degree of visibility of 31 goods and services ranging from cars and watches to medical insurance and education. Although bequests are not included in his list, the closest expenditure item surveyed, life insurance, ranks penultimate in terms of visibility. The high concentration of bequests on the upper tail of the wealth distribution is a well documented empirical regularity. Mulligan (1997) estimates that in the U.S. the proportion of estates bequeathing sufficient wealth to be subject to inheritance tax was between 2 and 4 percent in the period 1960-1995. The fact that most households do not leave a substantial bequest is consistent with the limited positionality of these transfers.

Finally, we place restrictions on the stationary distribution of productive endowments to guarantee that everyone's relative consumption is positive.

\subsection{Saving and Inequality}

The $i$-th individual of the generation born in period $t$ takes prices ${ }^{11}$ and the choices of the other members of his generation as given and chooses consumption in both periods of his life

\footnotetext{
${ }^{10}$ As (Frank 1985, p. 111) points out, "the sociological literature on reference group theory stresses that an individual's personal reference group tends to consist of others who are similar in terms of age". Along these lines our specification restricts interpersonal comparisons to individuals within the same generation. See Abel (2005) and Alonso-Carrera, Caballe and Raurich (2008) for an alternative specification of the reference group.

${ }^{11}$ Since we will focus on a single generation we drop time subscripts from prices.
} 
to maximize (3) subject to (1) and (2). Let's solve the problem in two stages. Given the level of saving, $s_{t}^{i}$, an old individual at time $t+1$ chooses $d_{t+1}^{i}$ and $b_{t+1}^{i}$ to maximize

$$
V \equiv \ln \left(d_{t+1}^{i}-\xi \gamma \bar{d}_{t+1}\right)+\mu \ln \left(b_{t+1}^{i}\right)
$$

subject to 2 . The solution to this problem is

$$
\begin{aligned}
d_{t+1}^{i} & =\frac{1}{1+\mu}\left(R s_{t}^{i}+\xi \gamma \mu \bar{d}_{t+1}\right) \\
b_{t+1}^{i} & =\frac{\mu}{1+\mu}\left(R s_{t}^{i}-\xi \gamma \bar{d}_{t+1}\right)
\end{aligned}
$$

and therefore

$$
V\left(R s_{t}^{i}\right)=(1+\mu) \ln \left(R s_{t}^{i}-\xi \gamma \bar{d}_{t+1}\right)+\ln \left(\frac{1}{1+\mu}\right)+\mu \ln \left(\frac{\mu}{1+\mu}\right)
$$

The young individual at time $t$ chooses $c_{t}^{i}$ and $s_{t}^{i}$ to maximize

$$
\ln \left(c_{t}^{i}-\gamma \bar{c}_{t}\right)+\beta V\left(R s_{t}^{i}\right)
$$

subject to (1). The necessary conditions for this problem imply

$$
\frac{R s_{t}^{i}-\xi \gamma \bar{d}_{t+1}}{\left(c_{t}^{i}-\gamma \bar{c}_{t}\right)(1+\mu)}=\beta R
$$

with the standard interpretation that along an optimal solution the $i$-th agent equates the marginal rate of substitution between first and second period choices to its relative price, the interest rate adjusted for the rate of time preference. Combining (7) and (1) we reach

$$
c_{t}^{i}[1+\beta(1+\mu)]=w^{i}+b_{t}^{i}+\beta(1+\mu) \gamma \bar{c}_{t}-\frac{\xi \gamma \bar{d}_{t+1}}{R}=y_{t}^{i}+\beta(1+\mu) \gamma \bar{c}_{t}-\frac{\xi \gamma \bar{d}_{t+1}}{R}
$$

We begin by characterizing the optimal behavior of the average household, i.e. the household with average income, $\bar{y}_{t}=\int_{0}^{1} b_{t}^{j} d j+\bar{w}$.

Combining (4), (5), (7) and (8) we obtain the level of saving of the average individual,

$$
\bar{s}_{t}=(1-\gamma) \beta(1+\mu(1-\xi \gamma)) \chi \bar{y}_{t}
$$

where $\chi \equiv \frac{1}{(1-\xi \gamma)+(1-\gamma) \beta(1+\mu(1-\xi \gamma))}$.

Saving for the average household is a constant fraction of his lifetime income. Combining (4)-(9) we obtain the remaining choices for the average household, 


$$
\bar{c}_{t}=\frac{(1-\xi \gamma)}{R \beta(1-\gamma)} \bar{d}_{t+1}=\frac{(1-\xi \gamma)}{R \beta \mu(1-\gamma)(1-\xi \gamma)} \bar{b}_{t+1}=(1-\xi \gamma) \chi \bar{y}_{t}
$$

We can use these results to characterize the behavior of the $i$-th individual of the same generation. Substitute (10) into (8) to reach first-period consumption. Combine it with (7) to reach his level of saving,

$$
s_{t}^{i}=\frac{\beta(1+\mu)}{1+\beta(1+\mu)}\left\{y_{t}^{i}-\gamma \phi_{s} \bar{y}_{t}\right\},
$$

where $\phi_{s} \equiv \frac{((1+\mu)(1-\xi \gamma)-\xi(1-\gamma)) \chi}{(1+\mu)}>0$.

It is straightforward to solve for the remaining optimal choices as functions of individual and average lifetime income,

$$
\begin{aligned}
c_{t}^{i} & =\frac{1}{1+\beta(1+\mu)}\left[y_{t}^{i}+\gamma \phi_{c} \bar{y}_{t}\right] \\
d_{t+1}^{i} & =\frac{R \beta}{1+\beta(1+\mu)}\left[y_{t}^{i}+\gamma \phi_{d} \bar{y}_{t}\right] \\
b_{t+1}^{i} & =\frac{R \beta \mu}{1+\beta(1+\mu)}\left[y_{t}^{i}-\gamma \phi_{b} \bar{y}_{t}\right]
\end{aligned}
$$

where

$$
\phi_{c} \equiv \beta((1+\mu)(1-\xi \gamma)-\xi(1-\gamma)) \chi>\phi_{d} \equiv(\xi \mu(1-\gamma) \beta+\xi-1) \chi>0,
$$

and

$$
\phi_{b} \equiv((1-\xi \gamma)+\xi(1-\gamma) \beta) \chi>0 .
$$

Consumption of the $i$-th household, (12) and (13), is made out of two components. The first increases in the household's lifetime income. The second reflects the influence of interpersonal comparisons and increases in the lifetime income of his reference group. As a result saving and bequests depend on relative, rather than absolute, income. When individual satisfaction depends on consumption comparisons across households the relevant variable driving saving choices is the comparison between individual $i$ 's lifetime income and the lifetime income of his reference group. The agents populating our economy are not only "disposed, as a rule and on the average, to be forward-looking animals" as those in (Modigliani and Brumberg 1954, p. 430) or Friedman (1957), but are also outward-looking animals as their choices are partially driven by the choices of other members of the community they live in. 
The following propositions summarize the implications of the model for saving rates and their interaction with income inequality.

Proposition 1. Under our assumptions, the (individual) saving rate increases with lifetime income.

$$
\frac{\partial s_{\text {rate }}^{i}}{\partial y^{i}}=\frac{\beta(1+\mu) \gamma \phi_{s}}{1+\beta(1+\mu)} \frac{\bar{y}}{\left(y^{i}\right)^{2}}>0
$$

Proof. Equation (11) implies the following saving rate out lifetime income,

$$
s_{\text {rate }}^{i} \equiv \frac{s^{i}}{y^{i}}=\frac{\beta(1+\mu)}{1+\beta(1+\mu)}\left(1-\gamma \phi_{s} \frac{\bar{y}}{y^{i}}\right)
$$

The result follows from differentiation of 15 .

In the absence of interpersonal comparisons, $\gamma=0$, the saving rate is proportional to lifetime income and therefore, as in the standard version of the permanent income hypothesis, the saving rate is independent of lifetime resources. Once we allow for consumption externalities, $\gamma>0$, the saving rate varies across the income distribution with poor households saving a smaller fraction of their resources than rich households. The introduction of interpersonal comparisons diverts resources from less positional uses -savings- to more positional ones - consumption when young. Furthermore, this diversion varies across the income distribution being stronger for poor households than for rich ones as the following proposition illustrates ${ }^{12}$.

Proposition 2. Under our assumptions, individual saving rates decrease with the level of income of the reference group and they do so more (less) for poor (rich) households.

Proof. Differentiate 15 to reach $\frac{\partial s_{\text {rate }}^{i}}{\partial \bar{y}}=-y^{i} \frac{\partial^{2} s_{\text {rate }}^{i}}{\partial \bar{y} \partial y^{i}}=-\frac{\beta(1+\mu) \gamma \phi_{s}}{1+\beta(1+\mu)} \frac{1}{y^{i}}<0$.

Finally, we can use this simple model to explore the impact of income inequality on individual saving. For simplicity, assume there is a generation, possibly the first, where the inherited bequest is equal to zero. Under this simplifying assumption income inequality is determined by the distribution of wages. A convenient measure of the dispersion of this distribution is the coefficient of variation, i.e. the ratio between the standard deviation and the mean of the

\footnotetext{
${ }^{12}$ There are two intuitive interpretations of these results. First, along the lines suggested by Alvarez-Cuadrado and Long (2012), in the presence of interpersonal comparisons the income elasticities of demand for consumption and saving vary across the income distribution. See their proposition 1 for details. Second, in line with the work of Atkeson and Masao (1996, 1997), the introduction of interpersonal comparisons induces an intertemporal elasticity of substitution (IES) that increases with income. To illustrate this point assume that $\xi=\mu=0$. The Euler equation for household $i$ is given by $\frac{d_{t+1}^{i}}{c_{t}^{i}}=\beta\left(1-\gamma \frac{\bar{c}_{t}}{c_{t}^{i}}\right) R$ where the term in brackets is proportional to the IES.
} 
wage distribution, $C V\left(w^{i}\right)=\frac{\sigma^{w}}{\bar{w}}$. With average saving given by 9 , we combine the standard deviation of wages with (11) to derive the standard deviation of saving,

$$
\sigma^{s}=\frac{\beta(1+\mu)}{1+\beta(1+\mu)} \sigma^{w}
$$

As a result the coefficient of variation of saving is given by $C V\left(s^{i}\right)=\Theta \frac{\sigma^{w}}{\bar{w}}$ with $\Theta \equiv(1+\mu) /$ $[(1+\beta(1+))(1+\mu(1-\xi \gamma))(1-\gamma) \chi] \geq 1$. So, an increase in income inequality leads to a more than proportional increase in saving inequality. Nonetheless, we are interested in the relationship between income inequality and saving rates. The following proposition illustrates this relationship.

Proposition 3. An increase in income inequality, measured as an increase in the coefficient of variation of wages, leads to an increase in inequality of saving rates.

Proof. Applying the Delta method to (15) we approximate the standard deviation for the saving rate by $\sigma^{s_{\text {rate }}} \approx \frac{\beta(1+\mu) \phi_{s}}{1+\beta(1+\mu)} \frac{\sigma^{w}}{\bar{w}}$ and therefore the coefficient of variation of the saving rates is given by,

$$
C V\left(s_{\text {rate }}^{i}\right) \approx \frac{\gamma((1+\mu)(1-\xi \gamma)-\xi(1-\gamma))}{(1+\beta(1+\mu))(1-\gamma)(1+\mu(1-\xi \gamma))} \frac{\sigma^{w}}{\bar{w}}
$$

As opposed to the standard version of the permanent income hypothesis, $\gamma=0$, where saving rates are independent of the level of income and therefore unaffected by the degree of income inequality, in the presence of interpersonal comparisons, $\gamma>0$, changes in the distribution of income lead to changes in the distribution of saving rates. Specifically an increase in income inequality is associated with an increase in the coefficient of variation of saving rates.

Remark to Proposition 3. The aggregate (average) saving rate is independent of the income distribution.

Since preferences are quasi-homothetic and capital markets are perfect saving is an affine function of income, a property that ensures that the distribution of income does not affect aggregate outcomes ${ }^{13}$. Along this dimension, our modelling approach is similar to that of Chatterjee (1994) and Caselli and Ventura (2000).

In the next section we will use PSID data to test these propositions.

\footnotetext{
${ }^{13}$ Notice that the timing of income is equivalent to perfect capital markets. See Alvarez-Cuadrado and Long (2012) for a characterization of stationary distributions of wealth in this model.
} 


\section{Empirical Analysis: Individual Saving and Inequality}

\subsection{Empirical Methodology}

There are several issues that we need to address before testing the empirical implications of the model presented in the previous section.

The first issue concerns the appropriate definition of saving. We use three different measures that capture different angles of savings behaviour. First, we use a broad measure of saving, the change in wealth between two consecutive waves of the PSID. Among other things this measure includes realized and unrealized capital gains on housing, other real estate, financial assets, and owned businesses. Second, we add estimates of saving through Social Security and private pensions to the change in wealth to obtain our most comprehensive measure of saving. Finally, we compute a measure of active saving as the difference between income exclusive of capital gains and consumption.

Second, we would like to recover the effect of permanent income on savings, but we do not observe permanent income. This is the key problem tackled by Dynan et al. (2004) and we will follow their approach. The PSID reports current income which is a noisy measure of permanent income since it includes transitory components of income and possibly some measurement error. We deal with this problem using consumption, food consumption, years of education of the head of the household, and average labor income as instruments for permanent income. As pointed out by Dynan et al. (2004), different instruments may suffer from different problems. For instance, to be able to use average labor income we need to assume that the transitory component in income is uncorrelated over time. One could also think that education could have a direct effect on saving decisions (Lusardi 1999), and this is why we include years of education of the head of the household as an explanatory variable in our regressions and only exclude it when we use education as an instrument. Furthermore instrumental variables provide an estimate for a specific group, those individuals whose behaviour is affected by the instrument (Imbens and Angrist 1995). Since not every individual is affected by the instruments in the same way, the estimated coefficients will vary according to the instruments used. Because of the different potential problems associated with each instrument and the heterogenous treatment effects, we perform our empirical analysis using one instrument at a time. Our goal is to show that the predictions of the model are robust to changes in specification.

Since current income, rather than permanent income, is also used in the construction of the saving rate similar, although less acute, problems arise. We reduce the impact of transitory income on the measured saving rate by computing savings over multi-year intervals and using averages of current income over these same periods. As a result, the remaining transitory 
income component or the presence of classical measurement error in our dependent variable is unlikely to cause a bias in our estimates.14.

Two other key variables for testing the propositions derived from our model are reference income and inequality. We measure income of the reference group as average income in the state of residence and we use the coefficient of variation of disposable income in the state of residence as our measure of inequality. Both variables vary across states and over time.

In contrast to Dynan et al. (2004), whose main focus is on the identification of the causal effect of income on saving rates, our focus is on the impact of reference income and inequality on saving rates and on the saving-income gradient. A causal interpretation of our results requires ruling out the possibility of reverse causality. One concern about reverse causality arises from the fact that saving rates vary systematically with income. As a consequence, it may be the case that a portion of the changes in income inequality are the result of past variation in saving rates. To deal with this concern, we show that results are similar when we use a measure of inequality calculated using labor income, which excludes capital income and therefore is independent of past saving choices 15 . The existence of factors that simultaneously affect both the dependent and independent variables could also affect the causal interpretation of our results. To deal with this, we include state dummies in the regression to capture potential unobserved drivers of differences in saving across states (e.g. cultural differences, say between Minnesota and California). To rule out a potential relationship between saving and inequality driven by business fluctuations we also include time dummies 16 .

Once the causal nature of our relationships of interest is established, we will provide additional evidence that they are indeed due to interpersonal comparisons and not to other factors. Even if the relationship between inequality and saving is causal, it could still be driven by factors other than interpersonal comparisons. For instance, differences in inequality across states may be associated with differences in redistributive policies that also affect saving. In section 4 , we address this concern by including political variables in the regression. Moreover, we verify that our results are not driven by interstate variation in housing prices that may be caused by differences in inequality across states (Matlack and Vigdor 2008). In addition to this, results

\footnotetext{
${ }^{14}$ Notice that the effect of the transitory component of income in the two wealth-based measures of the saving rate will tend to induce a negative correlation between saving rates and income biasing the coefficient of income downward. The concerns discussed so far were also faced by Dynan et al. (2004). We refer the interested reader to their paper for a more detailed discussion.

${ }^{15}$ Education is a particular type of saving and labor income reflects the returns to educational investment. Since education is not included in our measure of savings, reverse causality through this channel does not seem to be an issue. Nonetheless, in all our regressions we control for years of education.

${ }^{16}$ Furthermore, Runkle (1991), using PSID data, finds that aggregate shocks are not very important for individual consumption (and therefore saving) choices.
} 
on reference income and saving also provide evidence on the role of interpersonal comparisons.

Finally, all our regressions include as controls several factors that may affect saving (or consumption) decisions. We include age and age squared of the head of the household to control for life-cycle variation in saving rates (Huggett and Ventura 2000), years of education (Lusardi 1999), and a measure of household size (Attanasio and Browning 1995).

For most of our results we estimate a median regression with the savings rate as our dependent variable, and a measure of income, reference group income or regional inequality, and the other controls as explanatory variables. When we implement the IV estimation to recover the effect of permanent income we use a two-stage procedure. Standard errors are bootstrapped using 500 replications.

\subsection{Data}

We obtain all our information from the PSID, which is unique in providing a measure of assets for a panel of households. We use 8 wealth supplements covering the years 1984, 1989, 1994, 1999, 2001, 2003, 2005, and 2007. Using the panel dimension of the data, we estimate each household's change in wealth and active saving. As noted by Bosworth and Anders (2008), very wealthy households are underrepresented in the PSID, but for the bottom 95 percent of the wealth distribution, the PSID wealth data yields very similar results to data from the Survey of Consumer Finances (SCF) where this sample bias is not an issue.

We select our sample using the same criteria as Dynan et al. (2004). We restrict the sample to households with a head between 30 and 60 years of age, measured at the middle of the preceding 5-year period. As a result we avoid dealing with issues relevant to very young households, such as liquidity constraints, and to very old ones, such as retirement or acute health problems. We select households with an absolute value of active saving not larger than $\$ 1,050,000$ and with disposable income of at least $\$ 1,40017$ From the remaining sample, we drop households in the extreme $0.5 \%$ of the distribution of saving. We also drop observations for households that had a change in head. All the variables are adjusted for inflation using the price deflator for personal consumption expenditures and are reported using 2007 dollars. We end up with a sample of 24,036 observations about 8,063 households, with a minimum of 2,815 households in any given year.

For ease of comparison, we construct saving rates following the procedure outlined by Dynan et al. (2004). For our first measure of saving, $\Delta$ Wealth, we use information on the change

\footnotetext{
${ }^{17}$ These figures, expressed in 2007 dollars, are equivalent to those in Dynan et al. (2004), expressed in 1994 dollars.
} 
of eight asset categories net of their associated liabilities. These assets are home equity, other real estate, private business/farm, vehicles, transaction accounts, corporate equities, annuities/IRAs, and other savings. We also include information about non-collateralized debt. The resulting measure of saving is very broad and even includes realized and unrealized capital gains on housing.

Our second measure extends the previous one to include contributions to Social Security and company pension schemes, $\Delta$ Wealth + pensions. We include this as a separate measure since not all of these contributions result from individual choices. To calculate these contributions we add PSID data on employee's contributions to private pension plans and expected Social Security benefits ${ }^{18}$ We compute these benefits subtracting net marginal Social Security tax rates reported by Feldstein and Samwick (1992) and Cushing (2005) from gross Social Security tax rates. While the gross Social Security tax rate is easy to compute $-11.2 \%$ (12.5\% after 1995) of labor income up to $\$ 50,000$ - the net marginal tax rate (and the expected benefits) varies with income, age and marital status of the tax payer. For instance, in 1994 a household in Tennessee with four members whose head is 35 years old and earns the median income, around $\$ 46,000$, faced a net marginal Social Security tax rate of $5.59 \%$. As a result, his Social Security savings (or expected benefits) were $5.61 \%$ of his labor income.

The third measure, Active Saving, corresponds to the difference between income excluding capital gains and consumption. This measure includes net investments in private pensions and annuities, home equity, businesses, vehicles, stocks, cash assets and other financial assets plus redemption of other debt. It is also adjusted for transfers of assets in and out of the household 19 .

For the denominator of the saving rate we use either five-year or two-year averages of household income, depending on the periodicity of the PSID wealth supplements. Household income is total income after taxes and transfers including income from labor earnings, asset flows, private transfers, private pensions, public transfers, and Social Security pensions minus total taxes. When the numerator of the saving rate includes unrealized capital gains or pensions, its denominator, the measure of income, is adjusted accordingly. For each household, the saving rate is calculated as average saving over a multi-year period divided by average income over the same period. Finally, we refer to the three saving rates associated to these measures of saving as total saving rate, total saving rate plus pensions, and active saving rate, respectively.

Table 1 presents summary statistics for each of these variables. To reduce the influence of

\footnotetext{
${ }^{18}$ Unfortunately the PSID does not include employer's contributions to private pension plans. Since these contributions are mostly concentrated in high-income households, this omission will tend to reduce the gradient between saving rates and income.

${ }^{19}$ See Appendix I for a more detailed description of the construction of our saving measures.
} 
observations with very low income, the reported mean is computed dividing average annualized saving by average income over the period. Since the income measures used to compute the different saving rates differ, median income differs across measures. The reported median and mean saving rates suggest that the measures of saving differ in breadth and that the distribution of saving rates is skewed to the right. Comparing rows 1 and 2 one can see that the inclusion of pensions increases the saving rate for the median saver by 4 percentage points. The summary statistics for the distribution of saving rates are similar to those reported by Dynan et al. (2004) and Bosworth and Anders (2008).

Finally, this table also presents summary statistics for households's disposable income and the other variables included in our regressions. We report different measures of income that will be used at different stages of our analysis. Average labor income is computed using all observations on labor income for the time period that a household remains in the sample (1968-2007). On average this measure includes fourteen observations of yearly income.

\subsection{Saving Rates, Current Income and Inequality}

All the regressions include age, age squared and years of education of the head of the household, size of the household, and year and state dummies as controls. Although not reported, their associated coefficients are statistically significant throughout all our specification: 20 . In Table 2 , we test the relationship between income and the saving rate using our three different measures of saving. The first two columns show that the total saving rate increases with income. When we introduce a quadratic income term the relationship is convex. This is consistent with the findings of Dynan et al. (2004), who capture this non-linearity by allowing for quantile specific slopes. Column 1 indicates that an increase in income of $10 \%$ translates into an increase in the saving rate of half of a percentage point. Hence, increasing income of a household roughly at the median of the income distribution $(\$ 46,000)$ by $\$ 20,000$ increases his saving rate by 2.1 percentage points from about $10 \%$ to about $12 \% .{ }^{21}$ Using the estimates of Dynan et al. (2004), this same household would increase his saving rate by 2.2 percentage point: 22 . When we extend our saving measure to include Social Security benefits and private pensions, saving rates become slightly less responsive to income, but the relation remains positive and significant. Combined with a larger constant (not reported), this indicates that the inclusion of Social Security raises

\footnotetext{
${ }^{20}$ Furthermore, the coefficients on the socio-demographic controls have the expected signs. The effect of age is hump-shaped. The effect of education is positive, while that of household size is negative.

${ }^{21}$ The saving rate is computed for a 45 -year old head of a household with 4 members who has 12 years of education and lives in Oregon.

${ }^{22}$ When using the PSID, Dynan et al. (2004) find that increasing a household's income by 10,000 1982 dollars (about 20,000 2007 dollars) implies a change in the saving rate of 2.2 percentage points.
} 
the saving rate of the poor, weakening the saving-income relationship 23 . The relationship between saving and income remains positive and significant, although marginally weaker, when we consider active savings, which excludes capital gains.

Proposition 2 states that individual saving rates decrease with the level of income of the reference group, and more so for poor households. To test this proposition, we regress the saving rate on own income, our measure of income of the reference group -average state income-, and an interaction between the two variables. This interaction aims at capturing the differential impact of reference income across the income distribution. Our theory predicts that the coefficient on income of the reference group should be negative and the coefficient on the interaction term positive. Results from this regression are reported in Table 3. Since the log of each income measure ranges roughly from 8 to 13, the marginal effect of own income is positive for all agents above the bottom percentile. Considering an individual with income and regional income equal to the median of our sample, we find that the estimated marginal effects of income are similar to those reported in Table 2. The sign of the marginal effect of average state income varies across the income distribution. It is negative for poor households and positive for richer ones. This positive effect on the saving rates of richer households, particularly those with incomes above the mean, may be driven by the fact that average state income is an inadequate measure of their reference income. In the next section, once we instrument for permanent income, we will consider different reference groups for different individuals, all involving upward-looking comparisons, and show that Proposition 2 holds for a much larger fraction of the income distribution. Finally, the signs, size, and significance of the coefficients are similar for different measures of the saving rate and when we include a quadratic income term.

Proposition 3 states that an increase in income inequality leads to an increase in inequality of saving rates. In a way, our results in Table 2, that simply reproduce those of Dynan et al. (2004), already suggest this through a compositional effect. If the rich save more, increasing income inequality will increase saving inequality. In our empirical exercise, we can go one step further and test whether income inequality has a direct effect, beyond its impact through income, on saving rates and the saving-income relationship. To test this, we compute the coefficient of variation of disposable income for each year and state. We then regress the household saving rate on income, the coefficient of variation, and the interaction between the two. Our theory predicts that the coefficient on this interaction term should be positive, i.e.

\footnotetext{
${ }^{23}$ Dynan et al. (2004) find that adding estimates of saving through Social Security and private pensions to the total saving rate steepens the saving-income gradient. This difference might arise from the fact that their estimates of private pensions are more accurate than ours since they include employer's contribution to private plans.
} 
as inequality increases the gradient between saving rates and income becomes steeper. As always, we also include our set of controls which includes state dummies. We conduct this exercise for each one of the measures of saving. Table 4 shows the results of these regressions. Our coefficient of interest is positive and significant as predicted by the theory. The negative coefficient associated with inequality together with the positive interaction term implies that income inequality has a negative effect on saving rates for households with low levels of income. This negative effect becomes weaker, and after a certain point positive, as income increases. Since our results control for the level of income they suggest that income inequality has more than just a compositional effect on saving inequality ${ }^{24}$.

Results are similar when we use other measures of inequality. Table 5 reproduces this analysis using the Gini coefficient, the 90/10 percentile ratio and the standard deviation of the log of labor income. The basic picture that emerges from these extensions is the same: Inequality steepens the gradient between saving rates and income.

\subsection{Saving Rates, Permanent Income and Inequality}

In this section we reproduce the previous exercises using data on consumption, food consumption, average labor income, and education as instruments for permanent income. We follow a two-stage estimation procedure. In the first stage, we regress current income on one of the instruments, the set of control variables, and measures of reference income or inequality. The fitted values of this regression are the measures of permanent income that we use in the second stage, where we estimate a median regression with the saving rate as our dependent variable and predicted permanent income, reference income or inequality, and the other controls as explanatory variables.

Tables 6, 8 and 10 report these results. While point estimates vary with the choice of instrument, the magnitude and direction of the effects remain similar across specifications. The high value of the $F$-test of the excluded instrument implies that all the instruments are powerful. In the tables, we report results for the total saving rate and include a linear income term as a regressor. We obtain similar results for other measures of saving or when we include a quadratic income term. We report bootstrapped standard errors using 500 repetitions.

The first two columns of Table 6 present results using either consumption or food consump-

\footnotetext{
${ }^{24}$ In our model a mean-preserving spread in the distribution of income increases inequality in saving rates only through a compositional effect (since rich households become richer and poor households poorer). This is simply a consequence of the fact that this spread does not affect the level of reference income, which is simply average income. In the data changes in inequality most likely affect reference income. This change in reference income is behind the direct effect of inequality on saving.
} 
tion as an instrument. To measure consumption, we follow Dynan et al. (2004) and use a weighted average of food at home, food away from home, rental payments and imputed housing flows. The estimated relationship between income and saving rates becomes steeper and the negative impact of reference income in the lower tail of the income distribution becomes stronger. Next, in column 3 we use average labor income as an instrument for permanent income. In order to avoid problems of reverse causality, this instrument excludes any source of capital income that could be correlated with past saving decisions. Furthermore, this measure also excludes labor income from the current period. The signs and statistical significance of our coefficients of interest remain unchanged. Finally, the last column of this table reports results using years of schooling of the household head as an instrument ${ }^{25}$. Again the same picture emerges, saving rates increase with income, decrease with reference income, and more so for low-income households.

Because of the interaction, it is hard to read marginal effects of Table 6 directly. Therefore, the marginal effects of average state income at different percentiles of the income distribution are reported in Table 7. A marginal effect of -0.39 (row 1, column 1) indicates that for households in the 1st percentile of the income distribution, an increase in reference income of $10 \%$ reduces their saving rate by 0.04 percentage points. Although small, this effect is far from negligible, particularly if one considers that the median saving rate for households around that percentile is zero. This negative effect disappears between the 35th and 45th percentiles depending on the choice of instrument. As we pointed out in the previous section, this may be a consequence of the fact that average state income is not an appropriate reference level for richer households. In Table 8 we repeat the previous exercise restricting the sample to those households with income above the mean and recalculating reference income as the average income of this restricted sample. The sign, size, and significance of the coefficients remains unchanged. Nonetheless, the marginal effect of reference income now remains negative for households up to the 90th percentile of the (whole) income distribution, suggesting that increases in reference income reduce saving rates for most households. Table 9 summarizes these marginal effects for the restricted sample.

Table 10 explores the effects of income inequality on saving rates. The results are similar to those reported in the previous section. After controlling for permanent income, inequality has a negative impact on saving rates. This impact decreases with permanent income. Figure 2 illustrates the relationship between income and the saving rate implied by the coefficients reported in column 3 of Table 10. The solid line represents the income-saving relationship in

\footnotetext{
${ }^{25}$ In this case we exclude years of schooling from the set of controls.
} 
a state with low inequality (Oregon) and the broken line that in a state with high inequality (Texas). The gradient between saving rates and income is positive and becomes steeper in states with high inequality. The effect of inequality on saving rates is substantial. For instance, if we take a Texan at the median of the US income distribution, his total saving rate is 5 percentage points or $40 \%$ lower than that of a household with the same level of income living in Oregon. Notice that inequality reduces saving rates for most of the income distribution.

\subsection{Further Analysis}

\subsubsection{Sample composition and reverse causality}

In this section we explore the robustness of our results to differences in the sample composition. We recalculate our measures of reference income and inequality for each sample. In the analysis that follows we will use average labor income as an instrument for permanent income and we will focus on total saving - change in wealth- as our measure of saving. Nonetheless, results are similar for the other measures of saving or when we use alternative instruments for permanent income.

Excluding some observations at the top and bottom of the distribution of saving rates we obtain some indication of the sensitivity of our results to extreme values. Results for different trimmed samples are reported in Table 11. For ease of comparison, Column 1 reproduces the results from our baseline sample. In the remaining columns, we use a sample that drops households with saving rates at the top and bottom $1 \%$ and $5 \%$ of the distribution. Not surprisingly, since we are using median regression, results are unaffected by this trimming.

Table 12 presents results after restricting the sample to households with different levels of permanent income. On the one hand, excluding households with permanent income below a certain threshold, $\$ 10,000$ per year, we ensure that our results are not driven by the behavior of the very poor, whose saving rates may simply reflect the presence of a subsistence level of consumption. On the other hand, several authors have pointed out difficulties in rationalizing the saving behavior of very rich households in terms of a standard life-cycle model, see for instance Carroll (2000). Following a path that goes back, at least, to Weber (1958), Carroll (2000) argues that the pursuit of wealth for its own sake may be behind the saving choices of the very rich. Along these lines, excluding high-income households from our sample we ensure that our results are not driven by what Carroll (2000) refers to as the "spirit of capitalism". In both cases there is always a fraction of the income distribution that saves less as average income or inequality increase. These results suggest that our previous estimates were not driven by the behavior of very poor or very rich households. 
Trimming our sample by income is also useful to infer whether the presence of asset-based means tested government programs affects our results. These programs distort the saving incentives for marginally eligible households. In our context, this would be particularly important if the eligibility criteria or coverage change over time and this change is somehow correlated with inequality at the state level. By restricting our sample to households with permanent income over $\$ 35,000$, well above the eligibility criteria for most of these programs, we work with a set of households whose saving decisions should not be affected by the presence of these plans 26 . Columns 3 and 6 in Table 12 report the results of this exercise. The estimates remain similar to those reported using the full sample. In view of this we conclude that the presence of asset-based means tested government programs is unlikely to be driving our results.

Results in Table 13 are obtained using a sample that excludes those states with the highest and lowest levels of inequality. The three states with the highest level of inequality are Texas, New York and California. Those with the lowest level are Oregon, Washington and Wisconsin. Once more, the basic results remain unchanged.

Finally, one might think that differences in inequality across states may result from differences in the distribution of capital income that arise from different saving patterns across the income distribution. If this was the case, past differences in saving would be at the root of current differences in inequality. To show that our results are robust to this specific type of reverse causality, we repeat our basic regression constructing our measures of inequality using only labour income. Results, reported in Table 14, are consistent with our baseline estimates.

\subsubsection{Does redistribution matter?}

There are two, somewhat opposite, concerns related to the degree of redistribution at the state level. First, along the lines suggested by Alesina and Rodrik (1994), states with more inequality may engage in more redistribution of goods and services for which households typically save, for instance health care or higher education. This may reduce saving in that state, particularly for poor households since health costs represent a higher fraction of their income. In this case inequality has an effect on saving rates but it does so through a channel different from the one illustrated in our theoretical model. Inequality affects saving through redistribution rather than through interpersonal comparisons. A second, and probably less relevant, concern arises if more equal states are so as a result of redistribution, this redistribution mainly takes

\footnotetext{
${ }^{26}$ Although the eligibility criteria of these programs is often stated in terms of income and wealth, we restrict our sample only in terms of permanent income. By doing so, we assume that permanent income is highly correlated with wealth. Finally, it is worth noticing that these programs tend to have a stronger impact on the saving decisions of older households which are already excluded from our baseline sample.
} 
the form of consumption goods and services, and these goods are necessities, i.e. they have a low income elasticity of demand. One can think of food stamps or public transportation as goods that satisfy these requirements. If this is the case, redistribution will reduce more than proportionally the consumption needs of poor households providing them with additional room for saving. As a result, low-income households may save more in more equal states.

This second concern arises if differences in inequality do simply reflect differences in redistribution at the state level, i.e. more equal states are so because they redistribute more. Since we have data on pre-tax labor income and income after taxes and transfers we can test the extent to which redistribution drives the patterns of inequality across states ${ }^{27}$. We regress the estimated coefficient of variation of after-tax income on the coefficient of variation of pre-tax income, a time trend and regional dummies. The adjusted-R squared of this regression is very high, 0.95, and the coefficient on the coefficient of variation of pre-tax income is 0.83 . This suggests that pre-tax levels of inequality and state fixed characteristics account for almost all the variation in inequality in the data.

The first concern requires that more unequal states engage in more redistribution. To explore this hypothesis, we construct an index variable that indicates the political party of the state governor during the period in which the savings decision took place. This variable goes from 0, the state governor was a Democrat during the entire period, to 1, the state governor was a Republican during the entire period. As a first approximation, this variable should be a good proxy for the degree of generosity in the public provision of goods and services at the state level.

The correlation between regional inequality and our governor index is positive (10\%), indicating that on average, states governed by Republicans have higher inequality. The scenario described in the first concern thus appears questionable. In addition, Table 15 shows that when the governor index is included in our regressions, our results remain unchanged. Moreover, this index is only weakly significant, both on its own and when interacted with individual income. To the extent that differences in state governor capture differences in the generosity of the welfare state, our estimates of the effect of inequality on the saving-income relation do not seem to be driven by differences in redistribution at the state level.

\footnotetext{
${ }^{27}$ Notice that the denominator of any of our saving rates is income after taxes and transfers. This ensures that we do not overstate the saving rates of low-income households in more redistributive states inducing an spurious correlation between saving rates and inequality.
} 


\subsubsection{Housing prices}

It is possible that income inequality leads to increases in the prices of certain goods, particularly those that are locally in fixed supply. One can think of housing as a prime example. For instance, focusing on tight housing markets, Matlack and Vigdor (2008) find evidence consistent with this hypothesis. To the extent that this happens, higher housing prices would make residents of more unequal states poorer in real terms. As a consequence, they will tend to save less in line with the results of Dynan et al. (2004).

In Tables 16 and 17 we use a measure of real estate prices at the state level to test if the effect of inequality on savings results from differences in price levels. We include state level housing prices in our two standard specifications. Table 16 shows results using our standard measure of saving, while Table 17 shows results for a measure that excludes home equity.

Results in Table 16 show that higher house prices are associated with higher saving. This is only natural, as increases in real estate prices directly feed into higher saving rates through capital gains on housing. The effects of reference group income and inequality become slightly smaller but remain significant. When home equity is excluded from the measure of saving, house prices have a negative effect on saving, particularly for the poor. The effect of reference income weakens slightly although remains significant, while the effect of inequality remains qualitatively similar but loses significance. Note that while this measure of saving is useful to abstract from mechanical effects of changes in housing prices on saving through capital gains, it also misses most asset holdings for the majority of households and therefore is unlikely to yield strong results. 28

\subsubsection{Envy through life}

In line with our theoretical assumption, there is evidence that suggests that the importance of interpersonal comparisons may decrease over the life-cycle. The influence of reference groups seems to be more important for people who are starting their professional careers or are still trying to establish a certain status in society. As a result, this influence should become less important as people age as we assume in our theoretical model. In this section, we explore whether the data supports this assumption. For this purpose, we include in our benchmark exercise an interaction term between the key variable, income of the reference group or inequality, and age of the head of the household. The rest of the specification remains unchanged and, in

\footnotetext{
${ }^{28}$ Similarly, Bertrand and Morse (2012) argue that it is unlikely that inequality affects consumption through home prices. They find that households consume a larger share of their income in more unequal places independently of whether they are homeowners (who could finance consumption by loans against home equity) or renters.
} 
particular, it still includes age and age squared as controls29.

Results are reported in Table 18. The effect of the interactions involving age is always positive and significantly different from zero when using the income of the reference group. This indicates that the negative effect of reference income on saving rates decreases as the head of the household becomes older.

\subsubsection{The marginal propensity to save under upward-looking comparisons}

In this section we follow the procedure outlined by Dynan et al. (2004) to estimate the marginal propensity to save (MPS). In line with our simple model of interpersonal comparisons we have used average state income as reference income for all the household in each state. Nonetheless, Veblen (1899), Duesenberry (1949), and Frank (2007) eloquently argue that the behavior of successful individuals or groups sets the standard for the rest of the community. Ferrer-i Carbonell (2005) provides convincing microeconometric evidence on the importance of upwardlooking comparisons as a determinant of subjective well-being. In view of this evidence, a more realistic setup would allow for individuals to compare themselves with those who are ranked above them in the income distribution 30 . Under upward-looking comparisons, state average income is only a sensible reference point for those households in the lower part of the income distribution. Along these lines in this section we consider a different measure of reference income. We classify households in a given state and year into permanent income quintiles. We then estimate the reference income of each household as the average income of those quintiles above him. We do that for all the individuals except those in the top quintile, for whom we measure reference income as the average income of their own quintile 31

We exploit the panel dimension of our dataset and regress changes in total saving over time for a given household on changes in its income and changes in reference income. The coefficients associated with the income quintile dummies are our measures of the quintile specific MPS. Table 19 summarizes the results of this exercise. In both specifications the coefficients are statistically different from zero and, except for the bottom two quintiles, different from each other. In the second column we include the change in income of the reference group as a regressor. Its coefficient is negative and statistically significant. To illustrate the implications

\footnotetext{
${ }^{29}$ To obtain more variation in age, we extend our sample slightly by including households whose heads are between 60 and 66 years old, still below the official retirement age of 67 .

${ }^{30} \mathrm{We}$ will explore the theoretical implications of such an environment in the next section.

${ }^{31}$ Results excluding the top quintile are similar. Another possibility is to use average income of individuals with higher income as the reference for individuals in the highest income group. Although the results are unaffected, this specification suffers from important problems of multicollinearity between variation in households' level of income and variation in income of the reference group.
} 
of our result, consider again Figure 2(b), Between 1984 and 2007, for households in the lower half of the income distribution, average income increased by $\$ 2,018$ and average saving decreased by $\$ 1,844$. As discussed in the introduction, a MPS that increases with income is difficult to reconcile with these patterns. Using the estimates in column 1 that abstract from the impact of changes in reference income, one would predict that savings of the average household with income below the median should have increased by $\$ 129$ over this period. Results in column 2 allow us to control for the evolution of reference income. Since this measure increased by $\$ 13,284$ for this household, our estimates predict a drop in savings of $\$ 688.32$

\section{Aggregate Saving and Income Inequality}

In the previous model we have characterized the savings behavior of an heterogeneous-agent economy under the restrictive assumption that the reference group was common and equal to the average household in the economy. In this section we relax this assumption and revisit the relationship between aggregate savings and inequality. For the sake of illustration, we set $\xi=1$ and assume there are only two homogeneous income groups, denoted by the superscripts $H$ (rich) and $L$ (poor), with their wages given by $w^{H}$ and $w^{L}$ respectively, with $w^{H}>w^{L}$. The population is evenly distributed between these two group $\$ 33$. In line with the evidence discussed in the previous section, we assume that the reference group of the rich households is made up only of rich households while the reference group of poor households is composed of a weighted average of poor and rich households, with $\rho$ being the weight placed on poor households. As a result, reference consumption levels for the two groups are given respectively by

$$
\begin{aligned}
\bar{g}_{t}^{H}=\bar{c}_{t}^{H} & \text { and } & \bar{o}_{t+1}^{H}=\bar{d}_{t+1}^{H} \\
\bar{g}_{t}^{L}=\rho \bar{c}_{t}^{L}+(1-\rho) \bar{c}^{H} & \text { and } & \bar{o}_{t+1}^{L}=\rho \bar{d}_{t+1}^{L}+(1-\rho) \bar{d}_{t+1}^{H}
\end{aligned}
$$

The levels of saving for a rich and a poor household are given by

$$
\begin{gathered}
s_{t}^{H}=\beta(1+\mu(1-\gamma)) \pi y_{t}^{H} \\
s_{t}^{L}=\psi \beta\left[(1+\mu(1-\gamma \rho)) y_{t}^{L}-\mu \gamma(1-\rho) \pi y_{t}^{H}\right]
\end{gathered}
$$

\footnotetext{
${ }^{32}$ This presupposes that the household with average income in the bottom $50 \%$ of the income distribution is in the second quintile of the distribution. For this household, reference income therefore is the average income of the top three quintiles.

${ }^{33}$ For simplicity let's assume that in our generation of interest the bequest levels are common across types and equal to zero.

${ }^{34}$ See Appendix I for a detailed derivation.
} 
where $0<\psi \equiv \frac{1}{1+\mu \beta(1-\gamma \rho)+\beta}<\pi \equiv \frac{1}{1+\mu \beta(1-\gamma)+\beta}<1$.

Although this model has similar implications for individual saving than the previous one, its aggregate implications differ. The following proposition summarizes the impact of income inequality on aggregate savings in the presence of upward-looking comparisons.

Proposition 4. An increase in income inequality, a mean preserving spread in the distribution of wages, leads to a decrease in the aggregate (average) saving rate.

Proof. Defining the share of total income received by the rich households by $y_{s}^{H} \equiv \frac{y^{H}}{y^{H}+y^{L}}$, we combine (20) and (21) to derive the aggregate (average) saving rate as,

$$
s_{\text {rate }}^{\text {agg }}=y_{s}^{H} s_{\text {rate }}^{H}+\left(1-y_{s}^{H}\right) s_{\text {rate }}^{L}=\psi \beta\left((1+\mu(1-\gamma \rho))-2 \mu \gamma(1-\rho) \pi y_{s}^{H}\right)
$$

which is decreasing in the share of income received by rich households, $y_{s}^{H}$, and therefore in inequality.

In this framework, where upward-looking interpersonal comparisons matter, a mean preserving spread in the distribution of wages reduces the aggregate level of saving and therefore the aggregate saving rate. Although an increase in the wage of rich households leads to a proportional increase in their level of saving, leaving their saving rate unchanged, it is clear from (21) that this increase leads to a decrease not only in the level of saving of the poor but also in their saving rate. This decrease in saving of poor households is larger than the increase in saving of the rich.

Remark to Proposition 4. A distributionally-neutral increase in income, i.e. an increase in income that leaves unchanged the shares of aggregate income earned by rich and poor households, leaves the aggregate saving rate unchanged.

It is evident from (22) that the aggregate saving rate remains constant as long as the share of income of rich households remains constant. This implies this last remark.

\section{Empirical Analysis: Inequality and Aggregate Saving}

This last proposition states that an increase in inequality should reduce the aggregate saving rate. Our previous results suggest that this relationship holds in US micro data. For instance, Figure 4 indicates that individuals below the 85th percentile of the permanent income distribution save less in more unequal states. In this section, we test again Proposition 4 using panel data on six OECD countries. We estimate a simple saving specification that includes a measure of income inequality together with other standard determinants of saving. Our theory predicts that the coefficient on inequality should be negative. 
In contrast to previous cross-country studies on the determinants of aggregate saving that focus on measures of saving derived from the current account and therefore include elements of public or corporate saving (Edwards (1996), Schmidt-Hebbel and Serven (2000),Li and Zou (2004), Leigh and Posso (2009)), we will use a measure of the personal saving rate, from several OECD yearbooks, as our dependent variable. This measure is closer to our theory, which focuses on the determinants of household saving and abstracts from other components of national saving. Reasonably long series for the personal saving rate are not available for many countries, so we are forced to restrict our sample to Canada, France, Germany, Japan, the UK, and the US. Although the number of countries in our sample is not large, the time dimension is, covering the years 1955 to 2007 . Over this period our sample accounts for roughly $40 \%$ of world GDP.

Our measure of inequality is the fraction of total income accruing to the top five per cent of the income distribution ${ }^{35}$ We obtain this measure from Alvarado et al. (2012). This variable is available at a yearly frequency, except for Germany, where it is measured on a tri-annual basis. We follow Schmidt-Hebbel and Serven (2000) and include the age dependency ratio, the rate of growth of real GDP per capita, and the real interest rate as additional regressors ${ }^{36}$

Results are reported in Table 20. Column 1 shows a negative association between aggregate saving rates and income inequality, controlling for other determinants of saving. This relationship remains robust to the inclusion of country-fixed effects, as shown in column 2. In both specifications, the coefficient on inequality is negative and significant. The results from column 2 suggest that a percentage point increase in the share of income accruing to the top five percent of the income distribution is associated with a reduction in the personal saving rate of 0.26 percentage points. The evolution of the share of income of the top five percent, reported in Figure 2(c), together with this estimate suggests that around half of the decrease in the US personal saving rate (3.38 percentage points) can be associated to the process of income concentration that began more than three decades ago. ${ }^{37}$

In the next two columns, we make sure that our results are not due to unique events in

\footnotetext{
${ }^{35}$ We have estimated the same specification using other conventional indicators of inequality like the Gini coefficient or the ratio of the income shares of the richest 5 percent and the bottom 95 percent, with similar results.

${ }^{36}$ Notice that these authors include the level of per capita GDP and its square to capture the non-linear relationship between income and savings. This is particularly important when the variation in income through time or across countries is substantial. This is not the case in our sample. Nonetheless, the sign and significance of our coefficient of interest remains unchanged when we replace the rate of growth of per capita GDP by its level.

${ }^{37}$ The remaining coefficients also have the expected signs. The dependency ratio has a negative effect on the aggregate saving rate while in most specifications the real interest rate and the GDP growth rate have a positive effect.
} 
certain periods or business cycles. We do so by including decade dummies (column 3) and by using 5-year averages of our yearly data (column 4). In both cases, the negative relationship between saving and inequality remains significant. 38

At the aggregate level, the growth rate of per capita GDP and the interest rate are jointly determined with the saving rate. As a result, endogeneity becomes a concern. To deal with this issue, we estimate the model using Blundell and Bond's (1998) system GMM estimator with one lag. To further reduce endogeneity concerns, we use 5-year averaged data to extend the length of the lag. Columns 5 and 6 show that the coefficient on inequality remains negative and significant.

Finally, it is worth noticing that the timing of income in our theoretical model is equivalent to the assumption that credit markets are perfect. In this sense, one should expect the negative effect of inequality on aggregate saving through interpersonal comparisons to be reduced by the presence of credit market imperfections. These imperfections would prevent low income households from borrowing against their future income to emulate the consumption of richer households. To allow for this relationship, we control for a measure of financial development and its interaction with inequality in column 7. Among the several popular measures of financial development in the literature, we choose stock market capitalization because this measure, unlike ratios of credit or deposits to GDP, is less directly related to the saving rate. Results are consistent with the predictions of the model. The relationship between inequality and saving remains negative, and more so for higher levels of financial development 39

Despite limited availability of data - which limits the set of econometric techniques that can be used - we can thus establish a negative relationship between inequality and saving not only in individual-level data, but also in aggregate data. We see these results as promising; with more data on private saving, we could probe the robustness of these results with more detail and take the analysis to the level of the micro data analysis.

\section{Conclusions}

We have presented two models, four propositions, and some statistical evidence on the importance of interpersonal comparisons and its connection with the positive gradient between saving rates and income documented by Dynan et al. (2004). The intuition behind our theo-

\footnotetext{
${ }^{38}$ Furthermore, we estimate the model dropping one country at a time to verify that our results are not driven by the behaviour of any individual country. The basic results remain unchanged.

${ }^{39}$ Unfortunately, we are limited to using panel fixed effects with yearly data in this regression due to limited data availability. The World Bank's measure of stock market capitalization only covers the years 1989 to 2007. Taking five-year averages would leave us with only two observations per country.
} 
retical model is simple. When households care about relative consumption, the comparison of their consumption with that of their peers, the level of individual saving is determined by the interaction of two opposing forces. First, saving increases in the household's lifetime income, as in the permanent income hypothesis. Second, as a result of interpersonal comparisons, saving decreases in the lifetime income of the reference group, as in the relative income hypothesis.

In addition, our model suggests that the negative effect of reference income on saving rates is stronger for low-income households, that increases in income inequality translate into increases in inequality of saving rates, and that, in the presence of upward-looking interpersonal comparisons, changes in income inequality affect aggregate saving.

We use more than two decades of PSID data and a long, although thin, panel of OECD countries to test these implications. The data supports the basic predictions of our theory. Like Dynan et al. (2004), we find that saving rates increase in permanent income. Approximating income for the reference group by average state income, we find that, after controlling for own income, saving rates decrease in comparison income and they do so more for poor households. When we include a measure of income inequality, we find that those regions or periods with higher inequality are characterized not only by a more unequal distribution of saving rates but also by lower saving rates for most of the income distribution. These results do not seem to be driven by measurement error, reverse causality, differences in redistribution across time or states, or variation in real estate prices. Finally, although preliminary, our cross-country results suggest that the distribution of income may have important aggregate implications.

In their seminal paper, Dynan et al. (2004) conclude that "the rich do, indeed, save more" or, equivalently, that non-rich households save less. Our analysis suggests one of the reasons for these lower rates of saving, the importance of interpersonal comparisons. 


\section{$\begin{array}{ll}7 & \text { Tables and Figures }\end{array}$}

Figure 1: Motivation Figures.

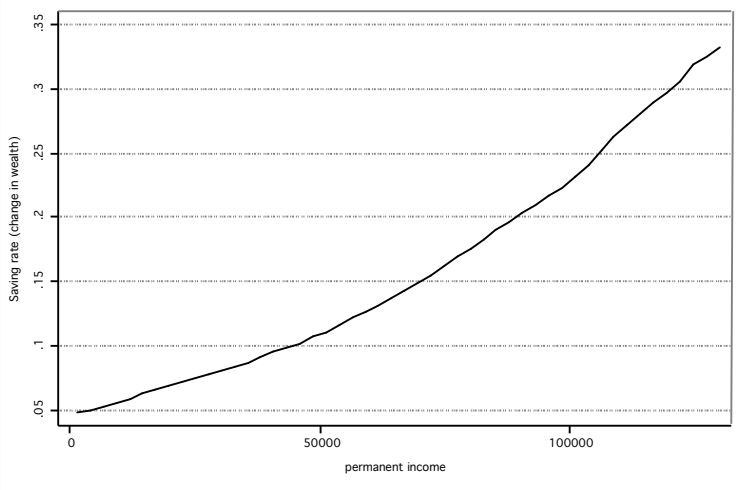

(a) Savings across the income distribution.

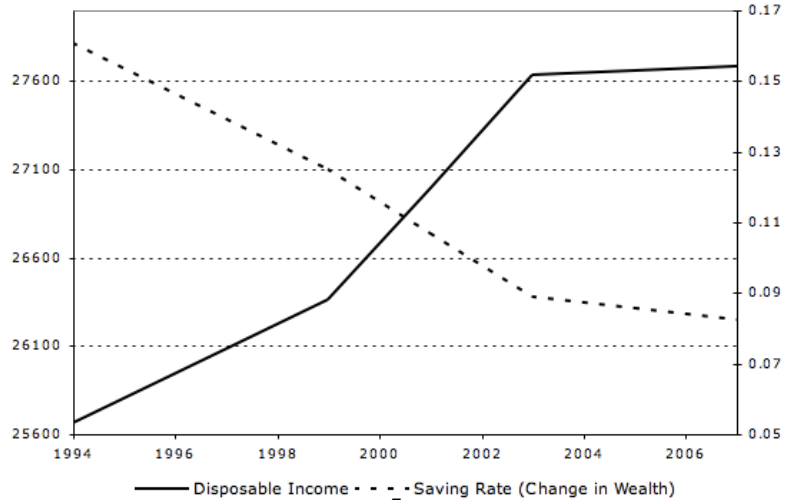

(b) Evolution of income and savings for households with low income.

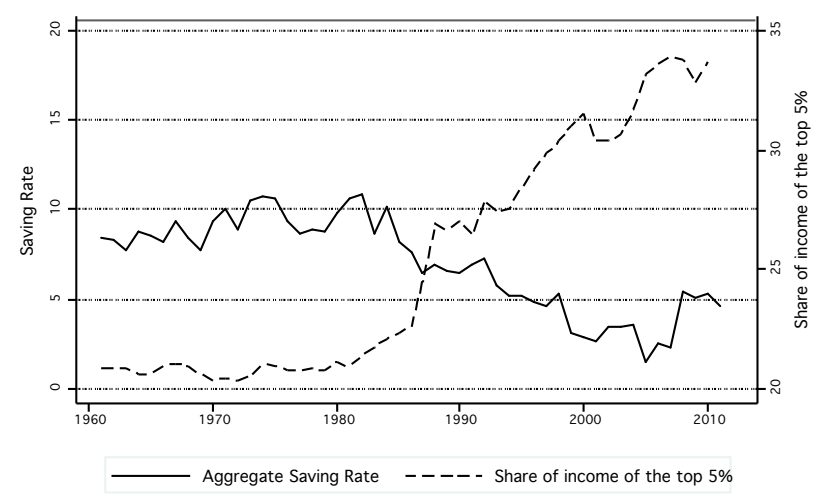

(c) Evolution of the household saving rate and inequality in the US.

Note: (a) Saving is the change in wealth over a period. Permanent income is the average labor income of the household over the period in which the household is in the sample (in 2007 dollars). (b) Saving rate is the average change in wealth over a period for households below the median of permanent income divided by their average disposable income. Disposable income is the average after tax household income in 2007 dollars for households below the median of permanent income. The figure reports 5-year moving averages except 1999, which is an average of 1994, 1999 and 2003. (c) Inequality is measured as the share of income of the top 5\% of the distribution from the update of Piketty and Saez (2003). The personal saving rate is obtained from the Federal Reserve Economic Data. 
Table 1: Summary statistics.

\begin{tabular}{lccc}
\hline \hline saving & median & mean & median income \\
\hline total saving rate & 0.07 & 0.21 & 47,115 \\
total saving rate + pension & 0.11 & 0.24 & 49,323 \\
active saving rate & 0.04 & 0.12 & 46,199 \\
income & median & mean & std. dev. \\
\hline disposable income (after tax) & 46,526 & 56,497 & 54,137 \\
disposable income (pre tax) & 56,332 & 72,093 & 83,346 \\
labour income (pre tax) & 53,510 & 69,304 & 82,824 \\
avg. labour income & 52,288 & 61,570 & 56,512 \\
demographics & median & mean & std. dev. \\
\hline head's years education & 12 & 13.09 & 2.44 \\
head's age & 45 & 45.53 & 8.05 \\
household size & 3 & 3.02 & 1.52 \\
\hline \hline
\end{tabular}

Note: All saving and disposable income measures are expressed in 2007 dollars. Measures of income used to compute the saving rates: $\Delta$ Wealth: disposable income + capital gains from housing, other real estate, business and stocks, $\Delta$ Wealth + pensions: disposable income + capital gains + employer contributions to Social Security and pensions. Median saving rate equals median of the ratio of saving to income. Average saving rate equals average saving divided by average income.

Table 2: Saving rates and income.

\begin{tabular}{lcccccc}
\hline \hline & \multicolumn{2}{c}{$\Delta$ Wealth } & \multicolumn{2}{c}{$\Delta$ Wealth + pensions } & \multicolumn{2}{c}{ Active } \\
\hline $\ln$ (income) & $0.049^{* * *}$ & $-0.418^{* * *}$ & $0.038^{* * *}$ & $-0.369^{* * *}$ & $0.039^{* * *}$ & $-0.299^{* * *}$ \\
& $(0.002)$ & $(0.024)$ & $(0.002)$ & $(0.027)$ & $(0.002)$ & $(0.021)$ \\
$\ln (\text { income })^{2}$ & & $0.023^{* * *}$ & & $0.020^{* * *}$ & & $0.017^{* * *}$ \\
& & $(0.001)$ & & $(0.001)$ & & $(0.001)$ \\
\hline Pseudo $R^{2}$ & 0.010 & 0.012 & 0.010 & 0.010 & 0.001 & 0.001 \\
$\mathrm{~N}$ & 24,036 & 24,036 & 24,036 & 24,036 & 24,036 & 24,036 \\
\hline \hline
\end{tabular}

Note: The column heading indicates the saving measure used. $\Delta$ Wealth refers to the change in wealth or total saving. Active saving is defined as total saving minus capital gains. Income is current after tax household income in 2007 dollars. All regressions also include controls for age, age squared, household size, head's education and year and state dummies which are not reported. Standard errors are reported in parentheses. ${ }^{* * *}$ significant at less than $1 \% ; * *$ significant at $5 \% ;{ }^{*}$ significant at $10 \%$ 
Table 3: Saving rates, income and reference group.

\begin{tabular}{lcccccc}
\hline \hline & \multicolumn{2}{c}{$\Delta$ Wealth } & $\Delta$ Wealth + pensions & \multicolumn{2}{c}{ Active } \\
\hline $\ln ($ income $)$ & $-0.974^{* * *}$ & $-1.022^{* * *}$ & $-0.899^{* * *}$ & $-1.002^{* * *}$ & $-0.742^{* * *}$ & $-0.761^{* * *}$ \\
& $(0.089)$ & $(0.086)$ & $(0.093)$ & $(0.095)$ & $(0.087)$ & $(0.078)$ \\
$\ln (\text { income })^{2}$ & & $0.021^{* * *}$ & & $0.017^{* * *}$ & & $0.016^{* * *}$ \\
& & $(0.001)$ & & $(0.001)$ & & $(0.001)$ \\
$\ln ($ state income $)$ & $-0.969^{* * *}$ & $-0.619^{* * *}$ & $-0.902^{* * *}$ & $-0.678^{* * *}$ & $-0.712^{* * *}$ & $-0.427^{* * *}$ \\
& $(0.089)$ & $(0.090)$ & $(0.093)$ & $(0.099)$ & $(0.087)$ & $(0.081)$ \\
$\ln ($ state income) $)$ & $0.095^{* * *}$ & $0.061^{* * *}$ & $0.087^{* * *}$ & $0.065^{* * *}$ & $0.073^{* * *}$ & $0.044^{* * *}$ \\
$\ln ($ income $)$ & $(0.008)$ & $(0.008)$ & $(0.009)$ & $(0.009)$ & $(0.008)$ & $(0.008)$ \\
\hline Pseudo $R^{2}$ & 0.011 & 0.012 & 0.010 & 0.010 & 0.001 & 0.001 \\
$\mathrm{~N}$ & 24,036 & 24,036 & 24,036 & 24,036 & 24,036 & 24,036 \\
\hline \hline
\end{tabular}

Note: The column heading indicates the saving measure used. $\Delta$ Wealth refers to the change in wealth or total saving. Active saving is defined as total saving minus capital gains. Income is current after tax household income in 2007 dollars. State income is the state level average of this measure. All regressions also include controls for age, age squared, household size, head's education and year and state dummies which are not reported. Standard errors are reported in parentheses. ${ }^{* * *}$ significant at less than $1 \% ; * *$ significant at $5 \% ;{ }^{*}$ significant at $10 \%$

Table 4: Saving rates, income and state inequality.

\begin{tabular}{lcccccc}
\hline \hline & \multicolumn{2}{c}{$\Delta$ Wealth } & $\Delta$ Wealth + pensions & \multicolumn{2}{c}{ Active } \\
\hline $\ln$ (income) & $0.037^{* * *}$ & $-0.417^{* * *}$ & $0.028^{* * *}$ & $-0.360^{* * *}$ & $0.030^{* * *}$ & $-0.302^{* * *}$ \\
& $(0.005)$ & $(0.024)$ & $(0.005)$ & $(0.024)$ & $(0.004)$ & $(0.025)$ \\
$\ln (\text { income })^{2}$ & & $0.023^{* * *}$ & & $0.020^{* * *}$ & & $0.017^{* * *}$ \\
& & $(0.001)$ & & $(0.001)$ & & $(0.001)$ \\
inequality & $-0.124^{* * *}$ & $-0.053^{* *}$ & $-0.117^{* * *}$ & $-0.039^{* *}$ & $-0.104^{* * *}$ & $-0.047^{*}$ \\
& $(0.043)$ & $(0.027)$ & $(0.043)$ & $(0.023)$ & $(0.038)$ & $(0.027)$ \\
inequality $\times$ & $0.011^{* * *}$ & $0.004^{* *}$ & $0.010^{* *}$ & $0.003^{*}$ & $0.010^{* * *}$ & 0.004 \\
$\quad \ln ($ income $)$ & $(0.004)$ & $(0.002)$ & $(0.004)$ & $(0.002)$ & $(0.004)$ & $(0.003)$ \\
\hline Pseudo $R^{2}$ & 0.011 & 0.012 & 0.010 & 0.010 & 0.001 & 0.001 \\
$\mathrm{~N}$ & 24,036 & 24,036 & 24,036 & 24,036 & 24,036 & 24,036 \\
\hline \hline
\end{tabular}

Note: The column heading indicates the saving measure used. $\Delta$ Wealth refers to the change in wealth or total saving. Active saving is defined as total saving minus capital gains. Income is current after tax household income in 2007 dollars. Inequality is measures as the coefficient of variation of disposable income per region an year. All regressions also include controls for age, age squared, household size, head's education and year and state dummies which are not reported. Standard errors are reported in parentheses. ${ }^{* * *}$ significant at less than $1 \%$; ** significant at $5 \%$; significant at $10 \%$ 
Table 5: Saving rates and current income - Other measures of inequality.

\begin{tabular}{lcccc}
\hline & $\mathrm{cv}($ income $)$ & gini & $\mathrm{p} 90 / \mathrm{p} 10$ & s.d(ln(income) \\
\hline $\ln ($ income $)$ & $0.037^{* * *}$ & 0.012 & $0.049^{* * *}$ & $0.033^{* * *}$ \\
& $(0.005)$ & $(0.017)$ & $(0.007)$ & $(0.010)$ \\
inequality & $-0.124^{* * *}$ & $-0.982^{* *}$ & -0.001 & $-0.183^{*}$ \\
& $(0.043)$ & $(0.434)$ & $(0.008)$ & $(0.110)$ \\
$\ln ($ income $) \times$ & $0.011^{* * *}$ & $0.087^{* *}$ & 0.0002 & $0.017^{*}$ \\
$\quad$ inequality & $(0.004)$ & $(0.040)$ & $(0.001)$ & $(0.010)$ \\
\hline Pseudo-R ${ }^{2}$ & 0.011 & 0.011 & 0.011 & 0.011 \\
$\mathrm{~N}$ & 24,036 & 24,036 & 24,036 & 24,036 \\
\hline \hline
\end{tabular}

Note: The column heading indicates the measure of inequality used. As a measure of saving we use change in wealth. All regressions also include controls for age, age squared, household size, head's education and year and state dummies which are not reported. Standard errors are reported in parentheses. ${ }^{* * *}$ significant at less than $1 \%$; ** significant at $5 \%$; significant at $10 \%$

Table 6: Saving rates, permanent income and reference group.

\begin{tabular}{lcccc}
\hline \hline & Consumption & $\begin{array}{c}\text { Food } \\
\text { Consumption }\end{array}$ & $\begin{array}{c}\text { Avg Labor } \\
\text { Income }\end{array}$ & Education \\
\hline $\ln ($ perm. income) & $-1.623^{* * *}$ & $-1.575^{* * *}$ & $-1.552^{* * *}$ & $-1.424^{* * *}$ \\
& $(0.250)$ & $(0.271)$ & $(0.174)$ & $(0.193)$ \\
$\ln$ (state income) & $-1.745^{* * *}$ & $-1.676^{* * *}$ & $-1.565^{* * *}$ & $-1.508^{* * *}$ \\
& $(0.240)$ & $(0.262)$ & $(0.171)$ & $(0.188)$ \\
$\ln$ (perm.income) $\times$ & $0.164^{* * *}$ & $0.157^{* * *}$ & $0.150^{* * *}$ & $0.143^{* * *}$ \\
$\ln ($ state income) & $(0.023)$ & $(0.025)$ & $(0.016)$ & $(0.018)$ \\
\hline Pseudo-R ${ }^{2}$ & 0.008 & 0.008 & 0.010 & 0.008 \\
$F$-excluded instruments & 2,753 & 760 & 10,492 & 5,088 \\
$\mathrm{~N}$ & 20,578 & 20,195 & 21,360 & 24,036 \\
\hline \hline
\end{tabular}

Note: The column heading indicates the instrument used in the regression. As a measure of saving we use change in wealth. Perm. income is a measure of permanent income estimated using an OLS regression, including the instrument and our set of controls. State income is the state level average of this measure. All regressions also include controls for age, age squared, household size, head's education and year and state dummies which are not reported. Standard errors are reported in parentheses. ${ }^{* * *}$ significant at less than $1 \% ;{ }^{* *}$ significant at $5 \%$; * significant at $10 \%$ 
Table 7: Marginal effect of state income on saving rates across the income distribution. Using permanent income.

\begin{tabular}{ccccccc}
\hline \hline \multicolumn{2}{c}{ perm. income distribution } & & \multicolumn{4}{c}{ marginal effect of state income } \\
\cline { 1 - 2 } \cline { 5 - 7 } percentile & $\begin{array}{c}\text { household } \\
\text { income }\end{array}$ & & consumption & $\begin{array}{c}\text { food } \\
\text { consumption }\end{array}$ & $\begin{array}{c}\text { average } \\
\text { labor income }\end{array}$ & education \\
\hline 1 & $\$ 3,664$ & & -0.396 & -0.385 & -0.329 & -0.336 \\
5 & $\$ 9,191$ & & -0.245 & -0.241 & -0.190 & -0.205 \\
10 & $\$ 14,597$ & & -0.169 & -0.168 & -0.121 & -0.139 \\
15 & $\$ 19,640$ & & -0.120 & -0.121 & -0.076 & -0.097 \\
20 & $\$ 23,882$ & & -0.088 & -0.091 & -0.047 & -0.069 \\
30 & $\$ 31,181$ & & -0.044 & -0.049 & -0.006 & -0.031 \\
40 & $\$ 38,533$ & & -0.010 & -0.015 & 0.025 & 0.000 \\
50 & $\$ 46,526$ & 0.021 & 0.014 & 0.054 & 0.026 \\
\hline \hline
\end{tabular}

Note: Marginal effects computed using results from table 7. All saving and disposable income measures are given in 2007 dollars.

Table 8: Saving rates, permanent income and reference group- changing the sample and the reference group

\begin{tabular}{lcccc}
\hline \hline & Consumption & $\begin{array}{c}\text { Food } \\
\text { Consumption }\end{array}$ & $\begin{array}{c}\text { Avg Labor } \\
\text { Income }\end{array}$ & Education \\
\hline $\ln ($ perm. income) & $-2.175^{* * *}$ & $-4.060^{* * *}$ & $-2.466^{* * *}$ & $-3.613^{* * *}$ \\
& $(0.664)$ & $(0.783)$ & $(0.537)$ & $(0.518)$ \\
$\ln$ (state income) & $-2.956^{* * *}$ & $-2.762^{* * *}$ & $-4.734^{* * *}$ & $-4.215^{* * *}$ \\
& $(0.687)$ & $(0.560)$ & $(0.818)$ & $(0.543)$ \\
$\ln ($ perm. income) $\times$ & $0.243^{* * *}$ & $0.405^{* * *}$ & $0.242^{* * *}$ & $0.362^{* * *}$ \\
$\ln ($ state income) & $(0.061)$ & $(0.072)$ & $(0.049)$ & $(0.048)$ \\
\hline Pseudo-R ${ }^{2}$ & 0.020 & 0.015 & 0.017 & 0.015 \\
$F$-excluded instruments & 1,391 & 283 & 4,459 & 869 \\
$\mathrm{~N}$ & 9,632 & 9,600 & 10,244 & 11,291 \\
\hline \hline
\end{tabular}

Note: The column heading indicates the instrument used in the regression. As a measure of saving we use change in wealth. Perm. income is a measure of permanent income estimated using an OLS regression, including the instrument and our set of controls. State income is the state level average of this measure. All regressions also include controls for age, age squared, household size, head's education and year and state dummies which are not reported. Standard errors are reported in parentheses. ${ }^{* * *}$ significant at less than $1 \% ;{ }^{* *}$ significant at $5 \%$; * significant at $10 \%$ 
Table 9: Marginal effect of state income on saving rates across the income distribution. Using permanent income and restricting the sample above average.

\begin{tabular}{ccccccc}
\hline \hline \multicolumn{2}{c}{ perm. income distribution } & & \multicolumn{4}{c}{ marginal effect of state income } \\
\cline { 1 - 3 } percentile & $\begin{array}{c}\text { household } \\
\text { income }\end{array}$ & & consumption & $\begin{array}{c}\text { food } \\
\text { consumption }\end{array}$ & $\begin{array}{c}\text { average } \\
\text { labor income }\end{array}$ & education \\
\hline 55 & $\$ 51,038$ & & -0.324 & -0.343 & -0.136 & -0.291 \\
60 & $\$ 55,778$ & & -0.302 & -0.307 & -0.114 & -0.259 \\
65 & $\$ 60,343$ & & -0.283 & -0.275 & -0.095 & -0.230 \\
70 & $\$ 65,582$ & & -0.263 & -0.241 & -0.075 & -0.200 \\
75 & $\$ 71,578$ & & -0.242 & -0.206 & -0.054 & -0.168 \\
80 & $\$ 78,636$ & & -0.219 & -0.168 & -0.031 & -0.134 \\
85 & $\$ 87,967$ & & -0.192 & -0.122 & -0.004 & -0.094 \\
90 & $\$ 101,830$ & & -0.156 & -0.063 & 0.032 & -0.041 \\
95 & $\$ 127,992$ & & -0.101 & 0.030 & 0.087 & 0.042 \\
\hline \hline
\end{tabular}

Note: Marginal effects computed using results from table 8. All saving and disposable income measures are given in 2007 dollars.

Table 10: Saving rates, permanent income and inequality.

\begin{tabular}{lcccc}
\hline \hline & Consumption & $\begin{array}{c}\text { Food } \\
\text { Consumption }\end{array}$ & $\begin{array}{c}\text { Avg Labor } \\
\text { Income }\end{array}$ & Education \\
\hline $\ln$ (perm. income) & $0.132^{* * *}$ & $0.103^{* * *}$ & $0.038^{* * *}$ & $0.090^{* * *}$ \\
& $(0.018)$ & $(0.022)$ & $(0.013)$ & $(0.010)$ \\
inequality & -0.149 & $-0.227^{*}$ & $-0.339^{* * *}$ & $-0.254^{* * *}$ \\
& $(0.127)$ & $(0.127)$ & $(0.134)$ & $(0.104)$ \\
$\ln$ (perm. income) & 0.013 & $0.020^{*}$ & $0.030^{* * *}$ & $0.023^{* * *}$ \\
$\quad$ inequality & $(0.012)$ & $(0.012)$ & $(0.012)$ & $(0.009)$ \\
\hline Pseudo-R & 0.009 & 0.008 & 0.010 & 0.008 \\
$F$-excluded instruments & 2,574 & 781 & 10,522 & 5,722 \\
$\mathrm{~N}$ & 20,578 & 20,195 & 21,360 & 24,036 \\
\hline \hline
\end{tabular}

Note: The column heading indicates the instrument used in the regression. As a measure of saving we use change in wealth. Perm. income is a measure of permanent income estimated using an OLS regression, including the instrument and our set of controls. Inequality is measured as the coefficient of variation of disposable income per state and year. All regressions also include controls for age, age squared, household size, head's education and year and state dummies which are not reported. Standard errors are reported in parentheses. *** significant at less than $1 \% ;{ }^{* *}$ significant at $5 \%{ }^{*}$ significant at $10 \%$ 
Figure 2: The saving rate by income percentile in states with different levels of inequality.

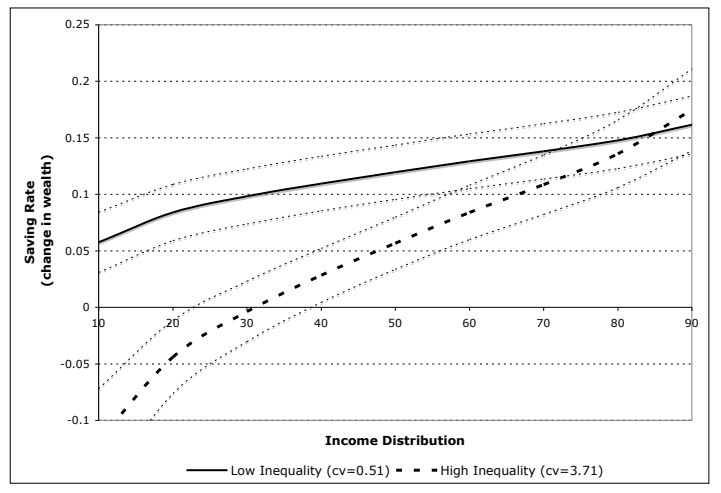

Note: Percentiles of the permanent income distribution on the x-axis. Saving rates are predicted values from the regression in column 4 in Table 10, for 2005, for a 45-year old head of a household with 4 members and 12 years of education. Percentiles of the permanent income distribution used in the prediction refer to the entire sample. Therefore, the level of income at each point is the same for both groups of states. The values of the coefficient of variation correspond to the minimum and maximum in the sample across regions. (note: low being Oregon and high being Texas.) 
Table 11: Saving rates and permanent income - altering the sample composition: eliminating extreme values of saving rates.

\begin{tabular}{lcccccc}
\hline & \multicolumn{3}{c}{ reference group } & \multicolumn{3}{c}{ inequality } \\
\cline { 2 - 7 } & baseline & excluding & excluding & baseline & excluding & excluding \\
& & $1 \%$ & $5 \%$ & & $1 \%$ & $5 \%$ \\
\hline $\ln ($ perm. income) & $-1.552^{* * *}$ & $-1.629^{* * *}$ & $-1.538^{* * *}$ & $0.038^{* * *}$ & $0.044^{* * *}$ & $0.039^{* * *}$ \\
& $(0.174)$ & $(0.180)$ & $(0.160)$ & $(0.013)$ & $(0.013)$ & $(0.011)$ \\
$\ln ($ state income) & $-1.565^{* * *}$ & $-1.643^{* * *}$ & $-1.538^{* * *}$ & & & \\
& $(0.171)$ & $(0.177)$ & $(0.157)$ & & & \\
$\ln$ (perm. income) $\times$ & $0.150^{* * *}$ & $0.158^{* * *}$ & $0.149^{* * *}$ & & & \\
$\quad$ (state income) & $(0.016)$ & $(0.017)$ & $(0.015)$ & & & \\
inequality & & & & $-0.339^{* * *}$ & $-0.291^{* * *}$ & $-0.305^{* * *}$ \\
& & & & $(0.134)$ & $(0.131)$ & $(0.119)$ \\
$\ln$ (perm. income) $\times$ & & & $0.030^{* * *}$ & $0.026^{* * *}$ & $0.027^{* * *}$ \\
inequality & & & & $(0.012)$ & $(0.012)$ & $(0.011)$ \\
\hline Pseudo $R^{2}$ & 21,360 & 21,162 & 19,472 & 21,360 & 21,162 & 19,472 \\
$\mathrm{~N}$
\end{tabular}

Note:The column heading indicates the way the sample has been altered. The percentage reported has been eliminated from both sides of the distribution. As a measure of saving we use change in wealth. Perm. income is a measure of permanent income estimated using an OLS regression, including the instrument and our set of controls. Inequality is measured as the coefficient of variation of disposable income per state and year. State income is the state level average of this measure. All regressions also include controls for age, age squared, household size, head's education and year and state dummies which are not reported. Standard errors are reported in parentheses. ${ }^{* * *}$ significant at less than $1 \% ; * *$ significant at $5 \% ;{ }^{*}$ significant at $10 \%$ 
Table 12: Saving rates and permanent income - altering the sample composition: restricting the sample by income.

\begin{tabular}{|c|c|c|c|c|c|c|}
\hline & \multicolumn{6}{|c|}{ Dependent variable: $\Delta$ Wealth } \\
\hline & \multicolumn{3}{|c|}{ reference group } & \multicolumn{3}{|c|}{ inequality } \\
\hline & $\begin{array}{c}\text { Income }> \\
10,000\end{array}$ & $\begin{array}{c}\text { Income }< \\
100,000\end{array}$ & $\begin{array}{c}\text { Income }> \\
35,000\end{array}$ & $\begin{array}{c}\text { Income }> \\
10,000\end{array}$ & $\begin{array}{c}\text { Income }< \\
100,000\end{array}$ & $\begin{array}{c}\text { Income }> \\
35,000\end{array}$ \\
\hline $\ln ($ perm.income $)$ & $\begin{array}{c}-2.514^{* * *} \\
(0.304)\end{array}$ & $\begin{array}{c}-1.763^{* * *} \\
(0.285)\end{array}$ & $\begin{array}{c}-3.950 * * * \\
(0.657)\end{array}$ & $\begin{array}{c}0.053^{* * *} \\
(0.017)\end{array}$ & $\begin{array}{c}0.027^{* *} \\
(0.013)\end{array}$ & $\begin{array}{c}0.136^{* * *} \\
(0.033)\end{array}$ \\
\hline $\ln ($ state income $)$ & $\begin{array}{c}-2.544^{* * *} \\
(0.300)\end{array}$ & $\begin{array}{c}-1.685^{* * *} \\
(0.280)\end{array}$ & $\begin{array}{c}-4.177^{* * *} \\
(0.659)\end{array}$ & & & \\
\hline $\begin{array}{l}\ln (\text { perm. income }) \times \\
\quad \ln (\text { state income })\end{array}$ & $\begin{array}{c}0.240^{* * *} \\
(0.028)\end{array}$ & $\begin{array}{c}0.173^{* * *} \\
(0.027)\end{array}$ & $\begin{array}{c}0.372^{* * *} \\
(0.059)\end{array}$ & & & \\
\hline inequality & & & & $\begin{array}{c}-0.432^{* * *} \\
(0.062)\end{array}$ & $\begin{array}{c}-0.362^{* * *} \\
(0.047)\end{array}$ & $\begin{array}{l}-0.199^{*} \\
(0.105)\end{array}$ \\
\hline $\begin{array}{l}\ln (\text { perm.income }) \times \\
\text { inequality }\end{array}$ & & & & $\begin{array}{l}0.039^{* *} \\
(0.016)\end{array}$ & $\begin{array}{c}0.033^{* * *} \\
(0.004)\end{array}$ & $\begin{array}{l}0.016^{*} \\
(0.010)\end{array}$ \\
\hline Pseudo $R^{2}$ & 0.010 & 0.007 & 0.011 & 0.010 & 0.006 & 0.010 \\
\hline $\mathrm{N}$ & 20,287 & 18,959 & 14,180 & 20,287 & 18,959 & 14,180 \\
\hline
\end{tabular}

Note: The column heading indicates the way the sample has been altered. As a measure of saving we use change in wealth. Perm. income is a measure of permanent income estimated using an OLS regression, including the instrument and our set of controls. State income is the state level average of this measure. Inequality is measured as the coefficient of variation of disposable income per state and year. State income is the state level average of this measure. All regressions also include controls for age, age squared, household size, head's education and year and state dummies which are not reported. Standard errors are reported in parentheses. ${ }^{* * *}$ significant at less than $1 \% ; * *$ significant at $5 \% ;{ }^{*}$ significant at $10 \%$ 
Table 13: Saving rates and permanent income - altering the sample composition: eliminating most and least unequal regions.

\begin{tabular}{lcccc}
\hline \hline & baseline & $\begin{array}{c}\text { excluding } \\
\text { low inequality }\end{array}$ & $\begin{array}{c}\text { excluding } \\
\text { high inequality }\end{array}$ & $\begin{array}{c}\text { excluding } \\
\text { high\&low }\end{array}$ \\
\hline $\ln$ (perm. income) & $0.038^{* * *}$ & $0.042^{* * *}$ & 0.025 & $0.038^{* * *}$ \\
& $(0.013)$ & $(0.011)$ & $(0.017)$ & $(0.016)$ \\
inequality & $-0.339^{* * *}$ & $-0.285^{* * *}$ & $-0.408^{* *}$ & $-0.249^{*}$ \\
& $(0.134)$ & $(0.114)$ & $(0.195)$ & $(0.140)$ \\
$\ln$ (perm. income) $\times$ & $0.030^{* * *}$ & $0.025^{* * *}$ & $0.038^{* *}$ & 0.022 \\
inequality & $(0.012)$ & $(0.010)$ & $(0.018)$ & $(0.017)$ \\
\hline Pseudo-R $\mathrm{R}^{2}$ & 0.010 & 0.010 & 0.009 & 0.008 \\
$\mathrm{~N}$ & 21,360 & 20,235 & 17,218 & 16,093 \\
\hline \hline
\end{tabular}

Note: The column heading indicates the regions that have been excluding from the sample: high inequality regions are Texas, New York and California. Low inequality regions are Oregon, Washington and Wisconsin. As a measure of saving we use change in wealth. Perm. income is a measure of permanent income estimated using an OLS regression, including the instrument and our set of controls. Inequality is measured as the coefficient of variation of disposable income per state and year. State income is the state level average of this measure. All regressions also include controls for age, age squared, household size, head's education and year and state dummies which are not reported. Standard errors are reported in parentheses. ${ }^{* * *}$ significant at less than $1 \%$; ** significant at $5 \%$; significant at $10 \%$ 
Table 14: Saving rates and permanent income - using only labour income.

\begin{tabular}{lcccc}
\hline & \multicolumn{2}{c}{ reference group } & \multicolumn{2}{c}{ inequality } \\
& baseline & labour income & baseline & labour income \\
\hline $\ln ($ perm. income) & $-1.553^{* * *}$ & $-1.166^{* * *}$ & $0.038^{* * *}$ & $0.023^{* * *}$ \\
& $(0.174)$ & $(0.182)$ & $(0.013)$ & $(0.013)$ \\
$\ln ($ state income) & $-1.565^{* * *}$ & $-1.187^{* * *}$ & & \\
& $(0.171)$ & $(0.175)$ & & \\
$\ln ($ perm. income) $\times$ & $0.151^{* * *}$ & $0.114^{* * *}$ & & \\
$\ln ($ state income) & $(0.016)$ & $(0.017)$ & & \\
inequality & & & $-0.339^{* * *}$ & $-0.457^{* * *}$ \\
& & & $(0.134)$ & $(0.132)$ \\
$\ln ($ perm. income) $\times$ & & $0.030^{* * *}$ & $0.042^{* * *}$ \\
inequality & & & $(0.012)$ & $(0.012)$ \\
\hline Pseudo- $\mathrm{R}^{2}$ & 0.010 & 0.009 & 0.010 & 0.010 \\
$\mathrm{~N}$ & 21,360 & 21,360 & 21,360 & 21,360 \\
\hline \hline
\end{tabular}

Note: The column heading indicates if the income of the reference group and the coefficient of variation of income (inequality measure) have been computed using total disposable income or only labour income per state and year. As a measure of saving we use change in wealth. Perm. income is a measure of permanent income estimated using an OLS regression, including the instrument and our set of controls. Inequality is measured as the coefficient of variation of disposable income per state and year. State income is the state level average of this measure. All regressions also include controls for age, age squared, household size, head's education and year and state dummies which are not reported. Standard errors are reported in parentheses. ${ }^{* * *}$ significant at less than $1 \% ;{ }^{* *}$ significant at $5 \%{ }^{*}$ significant at $10 \%$ 
Table 15: Saving rates and permanent income - controlling for redistribution.

\begin{tabular}{|c|c|c|c|c|}
\hline & \multicolumn{2}{|c|}{ baseline } & reference group & inequality \\
\hline $\ln ($ perm. income) & $\begin{array}{c}0.067^{* * *} \\
(0.006)\end{array}$ & $\begin{array}{c}0.062^{* * *} \\
(0.005)\end{array}$ & $\begin{array}{c}-1.503^{* * *} \\
(0.161)\end{array}$ & $\begin{array}{c}0.036^{* * *} \\
(0.012)\end{array}$ \\
\hline governor index & $\begin{array}{l}0.008^{*} \\
(0.005)\end{array}$ & $\begin{array}{l}-0.111 \\
(0.083)\end{array}$ & $\begin{array}{c}0.006 \\
(0.004)\end{array}$ & $\begin{array}{l}0.007^{*} \\
(0.004)\end{array}$ \\
\hline $\begin{array}{l}\ln (\text { perm } . \text { income }) \times \\
\text { governor index }\end{array}$ & & $\begin{array}{l}0.011^{*} \\
(0.007)\end{array}$ & & \\
\hline $\ln ($ state income $)$ & & & $\begin{array}{c}-1.521^{* * *} \\
(0.156)\end{array}$ & \\
\hline $\begin{array}{r}\ln (\text { perm. income }) \times \\
\ln (\text { state income })\end{array}$ & & & $\begin{array}{c}0.146^{* * *} \\
(0.015)\end{array}$ & \\
\hline inequality & & & & $\begin{array}{c}-0.359^{* * *} \\
(0.126)\end{array}$ \\
\hline $\begin{array}{l}\ln (\text { perm. income }) \times \\
\text { inequality }\end{array}$ & & & & $\begin{array}{c}0.032^{* * *} \\
(0.012)\end{array}$ \\
\hline Pseudo- $\mathrm{R}^{2}$ & 0.009 & 0.009 & 0.010 & 0.010 \\
\hline $\mathrm{N}$ & 21,076 & 21,076 & 21,076 & 21,076 \\
\hline
\end{tabular}

Note: As a measure of saving we use change in wealth. Perm. income is a measure of permanent income estimated using an OLS regression, including the instrument and our set of controls. The governor index goes from 0 , the state governor was a Democrat during the period in which the saving decision took place, to 1 , the state governor was a Republican during the entire period. Inequality is measured as the coefficient of variation of disposable income per state and year. State income is the state level average of this measure. All regressions also include controls for age, age squared, household size, head's education and year and state dummies which are not reported. Standard errors are reported in parentheses. ${ }^{* * *}$ significant at less than $1 \%$; ${ }^{*}$ significant at $5 \% ; *$ significant at $10 \%$ 
Table 16: Saving rates and permanent income - controlling for regional housing prices.

\begin{tabular}{|c|c|c|c|c|}
\hline & \multicolumn{2}{|c|}{ reference group } & \multicolumn{2}{|c|}{ inequality } \\
\hline & baseline & local prices & baseline & local prices \\
\hline $\ln ($ perm. income) & $\begin{array}{c}-1.553^{* * *} \\
(0.174)\end{array}$ & $\begin{array}{c}-0.947^{* * *} \\
(0.262)\end{array}$ & $\begin{array}{c}0.038^{* * *} \\
(0.013)\end{array}$ & $\begin{array}{c}-0.066^{* * *} \\
(0.029)\end{array}$ \\
\hline $\ln ($ state income $)$ & $\begin{array}{c}-1.565^{* * *} \\
(0.171)\end{array}$ & $\begin{array}{c}-0.920^{* * *} \\
(0.244)\end{array}$ & & \\
\hline $\begin{array}{r}\ln (\text { perm. income }) \times \\
\quad \ln (\text { state income })\end{array}$ & $\begin{array}{c}0.151^{* * *} \\
(0.016)\end{array}$ & $\begin{array}{c}0.085^{* * *} \\
(0.022)\end{array}$ & & \\
\hline inequality & & & $\begin{array}{c}-0.339^{* * *} \\
(0.134)\end{array}$ & $\begin{array}{l}-0.159^{*} \\
(0.089)\end{array}$ \\
\hline $\begin{array}{l}\ln (\text { perm. income }) \\
\text { inequality }\end{array}$ & & & $\begin{array}{c}0.030^{* * *} \\
(0.012)\end{array}$ & $\begin{array}{l}0.014^{*} \\
(0.008)\end{array}$ \\
\hline housing prices & & $\begin{array}{c}-0.006^{* * *} \\
(0.002)\end{array}$ & & $\begin{array}{c}-0.008^{* * *} \\
(0.002)\end{array}$ \\
\hline $\begin{array}{c}\ln (\text { perm income }) \times \\
\text { housing prices }\end{array}$ & & $\begin{array}{l}0.001^{* * *} \\
(0.0002)\end{array}$ & & $\begin{array}{c}0.001^{* * *} \\
(0.0003)\end{array}$ \\
\hline Pseudo-R ${ }^{2}$ & 0.010 & 0.010 & 0.010 & 0.010 \\
\hline $\mathrm{N}$ & 21,360 & 19,542 & 21,360 & 19,542 \\
\hline
\end{tabular}

Note: As a measure of saving we use change in wealth. Perm. income is a measure of permanent income estimated using an OLS regression, including the instrument and our set of controls. Housing prices is a measure of real estate prices at the state level. Inequality is measured as the coefficient of variation of disposable income per state and year. State income is the state level average of this measure. All regressions also include controls for age, age squared, household size, head's education and year and state dummies which are not reported. Standard errors are reported in parentheses. $* * *$ significant at less than $1 \%$; $* *$ significant at $5 \%$; ${ }^{*}$ significant at $10 \%$ 
Table 17: Saving rates (excluding home equity) and permanent income - controlling for regional housing prices.

\begin{tabular}{lcccc}
\hline & \multicolumn{2}{c}{ reference group } & \multicolumn{2}{c}{ inequality } \\
& baseline & local prices & baseline & local prices \\
\hline $\ln ($ perm income $)$ & $-0.491^{* * *}$ & $-0.339^{* * *}$ & $0.022^{* * *}$ & -0.005 \\
& $(0.119)$ & $(0.160)$ & $(0.007)$ & $(0.010)$ \\
$\ln ($ state income $)$ & $-0.497^{* * *}$ & $-0.343^{* * *}$ & & \\
& $(0.118)$ & $(0.162)$ & & \\
$\ln ($ perm income $) \times$ & $0.048^{* * *}$ & $0.032^{* * *}$ & & \\
$\ln ($ state income $)$ & $(0.012)$ & $(0.013)$ & & -0.032 \\
inequality & & & -0.061 & $-0.032)$ \\
& & & $(0.048)$ & $(0.052)$ \\
$\ln ($ perm income $) \times$ & & & 0.005 & 0.003 \\
inequality & & $-0.001^{* * *}$ & $(0.005)$ & $(0.006)$ \\
housing prices & & $(0.0003)$ & $-0.002^{* * *}$ \\
& & $0.0001^{* * *}$ & $(0.0003)$ \\
$\ln ($ perm income $) \times$ & & $(0.00003)$ & & $0.0002^{* * *}$ \\
housing prices & & 0.003 & $0.00005)$ \\
\hline Pseudo-R $\mathrm{R}^{2}$ & 0.003 & 19,542 & 21,360 & 19,542 \\
$\mathrm{~N}$ & 21,360 & &
\end{tabular}

Note: As a measure of saving we use change in wealth excluding home equity. Perm. income is a measure of permanent income estimated using an OLS regression, including the instrument and our set of controls. Housing prices is a measure of real estate prices at the state level. Inequality is measured as the coefficient of variation of disposable income per state and year. State income is the state level average of this measure. All regressions also include controls for age, age squared, household size, head's education and year and state dummies which are not reported. Standard errors are reported in parentheses. ${ }^{* * *}$ significant at less than $1 \%$; $* *$ significant at $5 \%$; significant at $10 \%$ 
Table 18: Saving rates and permanent income - Envy through life.

\begin{tabular}{|c|c|c|c|c|c|}
\hline \multicolumn{3}{|c|}{ reference group } & \multicolumn{3}{|c|}{ inequality } \\
\hline & baseline & age & & baseline & age \\
\hline $\ln ($ perm income $)$ & $\begin{array}{c}-1.553^{* * *} \\
(0.174)\end{array}$ & $\begin{array}{c}-1.466^{* * *} \\
(0.174)\end{array}$ & $\ln ($ perm income $)$ & $\begin{array}{c}0.038^{* * *} \\
(0.013)\end{array}$ & $\begin{array}{c}0.036^{* * *} \\
(0.012)\end{array}$ \\
\hline $\ln ($ state income $)$ & $\begin{array}{c}-1.565^{* * *} \\
(0.171)\end{array}$ & $\begin{array}{c}-1.659^{* * *} \\
(0.183)\end{array}$ & inequality & $\begin{array}{c}-0.339^{* * *} \\
(0.134)\end{array}$ & $\begin{array}{c}-0.369^{* * *} \\
(0.132)\end{array}$ \\
\hline $\begin{array}{l}\ln (\text { perm income }) \times \\
\quad \ln (\text { state income })\end{array}$ & $\begin{array}{c}0.150^{* * *} \\
(0.016)\end{array}$ & $\begin{array}{c}0.143^{* * *} \\
(0.016)\end{array}$ & $\begin{array}{c}\ln (\text { perm income }) \times \\
\ln (\text { inequality })\end{array}$ & $\begin{array}{c}0.030^{* * *} \\
(0.012)\end{array}$ & $\begin{array}{c}0.032^{* * *} \\
(0.012)\end{array}$ \\
\hline $\begin{array}{l}\text { Age } \times \\
\qquad \ln (\text { state income })\end{array}$ & & $\begin{array}{c}0.004^{* * *} \\
(0.001)\end{array}$ & $\begin{array}{l}\text { Age } \times \\
\quad \text { inequality }\end{array}$ & & $\begin{array}{c}0.0003 \\
(0.0006)\end{array}$ \\
\hline Pseudo- $\mathrm{R}^{2}$ & 0.010 & 0.010 & & 0.010 & 0.010 \\
\hline $\mathrm{N}$ & 21,360 & 21,360 & & 21,360 & 21,360 \\
\hline
\end{tabular}

Note: Columns 2 includes an interaction of average state income and age and column 4 includes an interaction of age and inequality. As a measure of saving we use change in wealth. Perm. income is a measure of permanent income estimated using an OLS regression, including the instrument and our set of controls. Housing prices is a measure of real estate prices at the state level. Inequality is measured as the coefficient of variation of disposable income per state and year. State income is the state level average of this measure. All regressions also include controls for age, age squared, household size, head's education and year and state dummies which are not reported. Standard errors are reported in parentheses. ${ }^{* * *}$ significant at less than $1 \%$; $* *$ significant at $5 \%$; significant at $10 \%$ 
Table 19: Marginal propensity to save.

\begin{tabular}{lcc}
\hline & \multicolumn{2}{c}{ change in saving } \\
& \multicolumn{2}{c}{$\Delta(\Delta$ Wealth $)$} \\
\hline Quantile 1 & 0.040 & 0.049 \\
& $(0.024)$ & $(0.027)$ \\
Quantile 2 & 0.064 & 0.067 \\
& $(0.016)$ & $(0.018)$ \\
Quantile 3 & $0.069^{*}$ & $0.078^{*}$ \\
& $(0.009)$ & $(0.011)$ \\
Quantile 4 & $0.139^{*}$ & $0.111^{*}$ \\
& $(0.008)$ & $(0.010)$ \\
Quantile 5 & $0.327^{*}$ & $0.328^{*}$ \\
& $(0.002)$ & $(0.003)$ \\
$\Delta$ income & & $-0.062^{* * *}$ \\
reference group & & $(0.008)$ \\
\hline Pseudo-R ${ }^{2}$ & 0.007 & 0.007 \\
$\mathrm{~N}$ & 16,798 & 14,236 \\
\hline \hline
\end{tabular}

Note: This table shows estimates of marginal propensity to save for each quintile obtained from changes in saving over time. The dependent variable is the change in household saving between periods divided by the number of years in the period. Reported in the table are marginal effects of changes in household income between periods by income quintile. They are computed from the coefficient on the interaction between the change in income and the income quintile indicators. Column 2 shows the results of the specification in which we included the change in income of the reference group, estimated as the average income of the quintiles above the quintile to which the individual belongs for a given space and a given year. Note that for quintile 5 we use the average income of the quintile as income of the reference group. Also included in the regression (coefficients not reported in the table) are the a set of indicator variables for permanent income, age, a quadratic term in age, the number of persons in the household, education and year and regional dummies. Standard errors are reported in parentheses. * The coefficient is significantly greater than that for the previous quintile, on the basis of a one-sided 5 percent test. 
Table 20: Aggregate saving rates and income inequality.

\begin{tabular}{|c|c|c|c|c|c|c|c|}
\hline & \multirow{2}{*}{$\begin{array}{c}\text { Pooled } \\
\text { OLS } \\
\text { baseline }\end{array}$} & \multicolumn{3}{|c|}{ fixed effects } & \multicolumn{2}{|c|}{ GMM } & \multirow{2}{*}{$\begin{array}{l}\text { fixed effects } \\
\text { financial } \\
\text { development }\end{array}$} \\
\hline & & baseline & $\begin{array}{c}\text { time } \\
\text { dummies }\end{array}$ & $\begin{array}{l}5 \text {-years } \\
\text { average }\end{array}$ & baseline & $\begin{array}{l}5 \text {-years } \\
\text { average }\end{array}$ & \\
\hline inequality & $\begin{array}{c}-0.297^{* * *} \\
(0.066)\end{array}$ & $\begin{array}{c}-0.262^{* * *} \\
(0.074)\end{array}$ & $\begin{array}{c}-0.162^{* *} \\
(0.080)\end{array}$ & $\begin{array}{l}-0.282^{*} \\
(0.158)\end{array}$ & $\begin{array}{c}-0.032^{* *} \\
(0.015)\end{array}$ & $\begin{array}{c}-0.119 * * \\
(0.055)\end{array}$ & $\begin{array}{c}-0.596^{* *} \\
(0.293)\end{array}$ \\
\hline $\begin{array}{l}\text { age dependency } \\
\text { ratio }\end{array}$ & $\begin{array}{c}-0.311^{* * *} \\
(0.109)\end{array}$ & $\begin{array}{c}-0.410^{* * *} \\
(0.120)\end{array}$ & $\begin{array}{l}-0.237 \\
(0.144)\end{array}$ & $\begin{array}{l}-0.157 \\
(0.294)\end{array}$ & $\begin{array}{l}-0.054 \\
(0.030)\end{array}$ & $\begin{array}{c}-0.065^{* *} \\
(0.130)\end{array}$ & $\begin{array}{c}-0.705^{* * *} \\
(0.225)\end{array}$ \\
\hline GDP growth & $\begin{array}{l}0.226^{* *} \\
(0.095)\end{array}$ & $\begin{array}{c}0.215^{* *} \\
(0.093)\end{array}$ & $\begin{array}{l}0.192^{*} \\
(0.098)\end{array}$ & $\begin{array}{c}0.800^{* *} \\
(0.315)\end{array}$ & $\begin{array}{c}-0.166^{* * *} \\
(0.046)\end{array}$ & $\begin{array}{l}0.333^{*} \\
(0.197)\end{array}$ & $\begin{array}{c}0.189 \\
(0.119)\end{array}$ \\
\hline $\begin{array}{l}\text { real interest } \\
\text { rates }\end{array}$ & $\begin{array}{c}0.513^{* * *} \\
(0.072)\end{array}$ & $\begin{array}{c}0.530^{* * *} \\
(0.072)\end{array}$ & $\begin{array}{c}0.566^{* * *} \\
(0.109)\end{array}$ & $\begin{array}{c}0.566^{* * *} \\
(0.149)\end{array}$ & $\begin{array}{c}0.003 \\
(0.115)\end{array}$ & $\begin{array}{c}0.077 \\
(0.034)\end{array}$ & $\begin{array}{c}0.192 \\
(0.161)\end{array}$ \\
\hline $\begin{array}{l}\text { financial } \\
\text { development } \\
\text { inequality } \times \\
\quad \text { fin.development }\end{array}$ & & & & & & & $\begin{array}{c}0.088^{* * *} \\
(0.026) \\
-0.003^{* *} \\
(0.001)\end{array}$ \\
\hline $\begin{array}{l}\text { Wald test } \\
(p \text {-value })\end{array}$ & 0.000 & 0.000 & 0.000 & 0.000 & 0.000 & 0.000 & 0.000 \\
\hline $\begin{array}{l}\text { Sargan test } \\
(p \text {-value }) \\
\operatorname{AR}(2)\end{array}$ & & & & & 0.792 & 0.230 & \\
\hline $\begin{array}{l}\text { ( } p \text {-value }) \\
\text { Observations }\end{array}$ & 216 & 216 & 216 & 41 & $\begin{array}{c}0.187 \\
214\end{array}$ & $\begin{array}{c}0.651 \\
39\end{array}$ & 86 \\
\hline
\end{tabular}

Note: The dependent variable is the country-level household saving rate. Source: OECD yearbooks (1975, 1980, 1983, 1988, 1991 and 2001). The first independent variable captures inequality and is the share of income received by the top $5 \%$ households. Source: Alvarado et al. (2012). The age dependency ratio is the population aged 65 and over as share of total population. Source: Groningen Growth and Development Centre, Total Economy Database, http://www.rug.nl/research/ggdc/data/total-economy-database-. GDP growth is real per capita GDP growth from the World Bank National Accounts. The real interest rate is interest on bonds minus inflation from the Federal Reserve Bank of St. Louis (Federal Reserve Economic Data). The measure of financial development is stock market capitalization over GDP. Source: Beck and Demirguc-Kunt (2009). The countries included in the sample are Canada, France, Germany, Japan, the UK and the US. The sample consists of annual observations covering 1954-2007, except for column 3 in which we use 5-years averages for all variables. Standard errors are reported in parentheses. ${ }^{* * *}$ significant at less than $1 \%$; ${ }^{* *}$ significant at $5 \%$; significant at $10 \%$ 


\section{References}

Abel, A. (1985), 'Precautionary Saving and Accidental Bequests', American Economic Review 75, 777-95.

Abel, A. (1990), 'Asset Prices Under Habit Formation and Catching Up With the Joneses', American Economic Review 80, 38-42.

Abel, A. (2005), 'Optimal Taxation When Consumers Have Endogenous Benchmark Levels of Consumption', Review of Economic Studies 72(1), 21-42.

Adreoni, J. (1989), 'Giving with Impure Altruism: Applications to Charity and Ricardian Equivalence', Journal of Political Economy 97, 1447-1458.

Alesina, A. and Rodrik, D. (1994), 'Distributive Politics and Economic Growth', The Quarerly Journal of Economics 109(2), 465-490.

Alonso-Carrera, J., Caballe, J. and Raurich, X. (2008), 'Estate taxes, consumption externalities, and altruism', Journal of Public Economics 92, 1751-1764.

Altonji, J. G. and Villanueva, E. (2007), 'The Marginal Propensity to Spend on Adult Children', The B.E. Journal of Economic Analysis Policy $7(1), 14$.

Alvarado, Atkinson, Piketty and Saez (2012), 'Income inequality in the United States, $1913-$ 1998', The Quarterly Journal of Economics 118(1), 1-39.

Alvarez-Cuadrado, F. and Long, N. V. (2012), 'Envy and Inequality', Scandinavian Journal of Economics 114(3), 949-973.

Arrondel, L., Parelman, S. and Pestieau, P. (1994), The effect of bequest motives on the composition and distribution of assets in France, in T. Tachibanaki, ed., 'Savings and Bequests', University of Michigan Press, Ann Arbor, pp. 229-244.

Atkeson, A. and Masao, O. (1996), 'Wealth-varying intertemporal elasticities of substitution: Evidence from panel and aggregate data', Journal of Monetary Economics 38(3), 507-534.

Atkeson, A. and Masao, O. (1997), 'Rate Of Time Preference, Intertemporal Elasticity Of Substitution, And Level Of Wealth', The Review of Economics and Statistics 79(4), 564572.

Attanasio, O. and Browning, M. (1995), 'Consumption over the Life Cycle and over the Business Cycle', American Economic Review 85(5), 1118-1137.

Attanasio, O., Hurst, E. and Pistaferri, L. (2012), 'The Evolution of Income, Consumption, and Leisure Inequality in The US, 1980-2010', NBER Working Papers, National Bureau of Economic Research $\mathbf{1 7 9 8 2}$.

Autor, D. H., Katz, L. F. and Kearney, M. S. (2008), 'Trends in US wage inequality: revising the revisionists', Review of Economics and Statistics 90(2), 300-323.

Barro, R. J. (1974), 'Are Government Bonds Net Wealth?', Journal of Political Economy 82(6), 1095-1117. 
Beck, T. and Demirguc-Kunt, A. (2009), 'Financial Institutions and Markets Across Countries and over Time: Data and Analysis', World Bank Policy Research Working Paper No.4943

Bernheim, B., Schleifer, A. and Summers, L. (1985), 'The Strategic Bequest Motive', Journal of Political Economy 93, 1045-75.

Bernheim, D. B., Skinner, J. and Weinberg, S. (2001), 'What accounts for the variation in retirement wealth among U.S. households?', The American Economic Review 91(4), 832857.

Bertrand, M. and Morse, A. (2012), 'Trickle-Down Consumption', Chicago Booth Working Paper.

Blinder, A. (1975), 'Distribution Effects and the Aggregate Consumption Function', Journal of Political Economy 83(3), 447-75.

Blundell, R. W. and Bond, S. (1998), 'Initial Conditions and Moment Restrictions in Dynamic Panel Data Models', Journal of Econometrics 87, 115-143.

Boskin, M. J. (1978), 'Taxation, saving and the rate of interest', Journal of Political Economy $\mathbf{7 6}(2), 3-27$.

Bosworth, B. and Anders, S. (2008), 'Savings and wealth accumulation in the PSID, 1984-2005', CRR Working Paper 2008-2.

Carroll, C. D. (2000), 'Portfolios of the Rich', NBER Working Papers 7826, National Bureau of Economic Research.

Carroll, C. D., Overland, J. and Weil, D. N. (2000), 'Saving and Growth with Habit Formation', American Economic Review 90(3), 341-355.

Carroll, C. D. and Weil, D. N. (1994), 'Saving and growth: a reinterpretation', CarnegieRochester Conference Series on Public Policy 40(1), 133-19.

Caselli, F. and Ventura, J. (2000), 'A Representative Consumer Theory of Distribution', American Economic Review 90(4), 909-926.

Charles, K. K., Hurst, E. and Roussanov, N. (2009), 'Conspicuous Consumption and Race', The Quarterly Journal of Economics 124(2), 425-467.

Chatterjee, S. (1994), 'Transitional Dynamics and the Distribution of Wealth in a Neoclassical Growth Model', Journal of Public Economics 54, 97-119.

Clark, A., Frijters, P. and Shields, M. (2008), 'Relative Income, Happiness, and Utility: An Explanation for the Easterlin Paradox and Othe Puzzles', Journal of Economic Literature 46, $95-144$.

Coleman, J. (1961), The Adolescent Society, Free Press, New York.

Corneo, G. and Jeanne, O. (1998), 'Social organization, status, and savings behavior', Journal of Public Economics 70(1), 37-51.

Corsaro, W. and Eder, D. (1990), 'Children's Peer Cultures', Annual Review of Sociology 16, 197-220. 
Cushing, M. J. (2005), 'Net Marginal Social Security Tax Rates over the Life-Cycle', National Tax Journal 58(2), 227-246.

Cutler, D. M. and Katz, L. F. (1992), 'Rising Inequality? Changes in the Distribution of Income and Consumption in the 1980's', American Economic Review 82(2), 546-51.

Davies, J. and Shorrocks, A. (1999), The distribution of wealth, in A. Atkinson and F. Bourguignon, eds, 'Handbook of Income Distribution', Elsevier, Amsterdam, pp. 605-675.

De Nardi, M., French, E. and Jones, J. B. (2010), 'Why Do the Elderly Save? The Role of Medical Expenses', Journal of Political Economy 118(1), 39-7.

Deaton, A. (1991), 'Saving and liquidity constraints', Econometrica 59(5), 1221-1248.

Duesenberry, J. (1949), Income, Saving and the Theory of Consumer Behavior, Harvard University Press, Cambridge, MA.

Dynan, K. and Ravina, E. (2007), 'Increasing Income Inequality, External Habits, and SelfReported Happiness', American Economic Review 97(2), 226-231.

Dynan, K., Skinner, J. and Zeldes, S. (2004), 'Do the rich save more?', Journal of Political Economy 112(2), 397-444.

Easterlin, R. (1995), 'Will Raising the Incomes of All Increase the Happiness of All? ', Journal of Economic Behavior and Organization 27, 35-47.

Easterlin, R. (2010), Does Economic Growth Improve the Human Lot? Some Empirical Evidence, in P. A. David and M. W. Reder, eds, 'Nations and Households in Economic Growth: Essays in Honour of Moses Abramovitz', Academic Press, New York, pp. 89-125.

Edwards, S. (1996), 'Why are Latin Americas savings rates so low? An International comparative analysis', Journal of Development Economics 51, 5-44.

Feldstein, M. and Samwick, A. (1992), 'Social Security Rules and Marginal Tax Rates', NBER Working Papers 3962, National Bureau of Economic Research.

Ferrer-i Carbonell, A. (2005), 'Income and well-being: an empirical analysis of the comparison income effect', Journal of Public Economics 89(5-6), 997-1019.

Frank, R. (1985), Choosing the Right Pond: Human Behavior and the Quest for Status, Oxford University Press, New York and Oxford.

Frank, R. (2007), Falling Behind: How Income Inequality Harms the Middle Class, University of California Press, Berkley.

Friedman, M. (1957), A Theory of the Consumption Function, Princeton University Press, Princeton.

Gali, J. (1994), 'Keeping Up with the Joneses: Consumption Externalities, Portfolio Choice, and Asset Prices', Journal of Money, Credit, and Banking 26, 1-8.

Heffetz, O. (2011), 'A Test of Conspicuous Consumption: Visibility and Income Elasticities', Review of Economics and Statistics 93(4), 1101-1117.

Hong, K. (1995), Income distribution and aggregate saving, unpublished manuscript, Harvard University Press, Cambridge, MA. 
Huggett, M. and Ventura, G. (2000), 'Understanding why high income households save more than low income households', Journal of Monetary Economics 45(2), 361-397.

Hurst, E. and Lusardi, A. (2004), 'Liquidity Constraints, Household Wealth, and Entrepreneurship', Journal of Political Economy 112(2), 319-347.

Imbens, G. and Angrist, J. D. (1995), 'Identification and Estimation of Local Average Treatment Effects', Econometrica 62(2), 467-475.

Katz, L. F. and Autor, D. H. (1999), Changes in the wage structure and earnings inequality, in O. Ashenfelter and D. Card, eds, 'Handbook of Labor Economics', Vol. 3, Elsevier, chapter 26, pp. 1463-1555.

Kopecky, K. and Koreshkova, T. (2010), 'The impact of medical and nursing home expenses and social insurance', Federal Reserve Bank of Atlanta Working Paper 2010-19.

Krueger, D. and Perri, F. (2006), 'Does income inequality lead to consumption inequality? evidence and theory', Review of Economic Studies 73(1), 163-193.

Kuznets, S. (1942), Uses of National Income in Peace and War, National Bureau of Economic Research, New York.

Leigh, A. and Posso, A. (2009), 'Top Incomes And National Savings', Review of Income and Wealth 55(1), 57-74.

Levine, A., Frank, R. H. and Dijk, O. (2010), 'Expenditure Cascades'. http://ssrn.com/ abstract=1690612orhttp://dx.doi.org/10.2139/ssrn.1690612.

Li, H. and Zou, H.-f. (2004), 'Savings and Income Distribution', Annals of Economics and Finance, Society for AEF 5(2), 245-270.

Liu, W.-F. and Turnovsky, S. (2005), 'Consumption externalities, production externalities, and long-run macroeconomic efficiency', Journal of Public Economics 89(5-6), 1097-1129.

Ljungqvist, L. and Uhlig, H. (200), 'Tax policy and aggregate demand management under catching up with the Joneses', American Economic Review 90, 356-366.

Lusardi, A. (1999), Information, Expectations, and Savings for Retirement, in H. Aaron, ed., 'Behavioral Dimensions of Retirement Economics', Brookings Institution Press and Russell Sage Foundation, Washington, D.C.

Luttmer, E. F. (2005), 'Neighbors as Negatives: Relative Earnings and Well-Being', Journal of Economics 120(3), 963-1002.

Matlack, J. L. and Vigdor, J. L. (2008), 'Do rising tides lift all prices? Income inequality and housing affordability', Journal of Housing Economics 17(3), 212-224.

Mayer, T. (1966), 'The Propensity to Consume Permanent Income', American Economic Review 56, 1158-1177.

Mayer, T. (1972), Permenent Income, Wealth, and Consumption: A Critique of the Permanent Income Theory, the Lif-Cycle Hypthesis, and Related Theories., Berkley University Press, California. 
Moav, O. and Neeman, Z. (2010), 'Status and Poverty', Journal of the European Economic Association 8(2-3), 413-420.

Modigliani, F. (1970), he life-cycle hypothesis and intercountry differences in the saving ratio, in M. F. S. W. A. Eltis and J. N. Wolfe, eds, 'Induction, growth, and trade: essays in honour of Sir Roy Harrod', Oxford University Press, Oxford, pp. 197-225.

Modigliani, F. and Brumberg, R. H. (1954), Utility analysis and the consumption function: an interpretation of cross-section data, in K. K. Kurihara, ed., 'Post-Keynesian Economics', N.J. Rutgers University Press, New Brunswick, pp. 388-436.

Mulligan, C. (1997), Parental Priorities and Economic Inequality, The University of Chicago Press, Chicago.

Oswald, A. J. (1997), 'Happiness and Economic Performance', The Economic Journal 107(445), 1815-31.

Person, T. and Tabellini, G. (1994), 'Is Inequality Harmful for Growth?', American Economic Review 84(3), 600-621.

Piketty, T. and Saez, E. (2003), 'Income inequality in the United States, 1913-1998', The Quarterly Journal of Economics 118(1), 1-39.

Quadrini, V. (1999), 'Growth, learning and redistributive policies', Journal of Public Economics 74(2), 263-297.

Runkle, D. E. (1991), 'Liquidity constraints and the permanent-income hypothesis: Evidence from panel data', Journal of Monetary Economics 27(1), 73-98.

Schmidt-Hebbel, K. and Serven, L. (2000), 'Does income inequality raise aggregate saving?', Journal of Development Economics 61, 417-446.

Simmons, R. and Blyth, D. (1987), Moving Into Adolescence: The Impact of Pubertal Change and School Context, Aldine Press, New York.

Slesnick, D. (2001), Consumption and Social Welfare, Cambridge University Press, Cambridge.

Stevenson, B. and Wolfers, J. (2008), 'Economic Growth and Subjective Well-Being: Reassessing the Easterlin Paradox', Brookings Papers on Economic Activity, Economic Studies Program, The Brookings Institution 39(1-(Spring)), 1-102.

Veblen, T. (1899), The Theory of the Leisure Class: An Economic Study of Institutions, Modern Library, New York.

Weber, M. (1958), The Protestant Ethic and the Spirit of Capitalism, Routledge Classics, London, UK.

Wendner, R. (2012), 'Ramsey, Pigou, heterogenous agents, and non-atmospheric consumption externalities', Graz Economics Papers GEP 01-2012. 


\section{Data Appendix (for online publication)}

We use household and individual data and the wealth supplements from the PSID for the period 1984-2007. Unless otherwise noted, the same methodology is used to construct variables for the different periods between 1984-2007. All the variables are adjusted for inflation using the price deflator for personal consumption expenditures and are reported using 2007 dollars.

We use three different saving measures; active saving, change in wealth, and change in wealth plus pension and social security. All of the wealth and active saving components are from the wealth and active saving supplement files of the PSID, which give detailed information on wealth levels and components of active saving for 1984, 1989, 1994, 1999, 2001, 2003, 2005 and 2007. The saving variables are constructed in the following way:

a. Change in Wealth: Computed as the difference between real net worth in a given period and real net worth in the preceding period. Real net worth is constructed as the sum of values of seven asset types: Home equity, other real estate, private business and farms, vehicles, transaction accounts, corporate equities, annuities and IRAs and other savings, net of debt. Net worth does not include either defined benefit or defined contribution pension savings. If respondents failed to provide an estimate of a wealth component or if they could only provide a range of values, the PSID staff uses imputation procedures.

b. Active Saving: this measure is designed to be similar to the traditional income minus consumption measure of saving. It equals the change in wealth over a given period minus capital gains, for example on housing or stocks. Since capital gains questions were not directly asked, the measure is built in part from questions about saving flows.

First, consider active savings in the main residence: if a household has not changed home during the period, this consists in the change in the mortgage liability. If the home changed during the period, the change in home equity also enters. Secondly, active 
savings in assets subject to capital gains consist in purchases and sales of other real estate, businesses and corporate equities. Finally, active savings in fixed income and other assets consists in changes in the holdings of "other savings" and transaction accounts, minus changes in non-collateralized debt.

c. Change in wealth plus pensions and social security: This variable adjusts the change in wealth measure above for saving through pension and social security contributions. Its construction follows Dynan et al. (2004). Since our sample is longer, we use imputed social security taxes from Feldstein and Samwick (1992) for the years up to 1995, and estimates from Cushing (2005) after that. These papers provide estimates of net marginal tax rates through social security contributions for different demographic groups. The difference between the social security contribution rate (a 11.2\% payroll tax on labor income up to $\$ 50,000$ until 1995, $12.5 \%$ afterwards) and the implied tax rate constitutes saving. This is straightforward for singles. Spouses may contribute separately or not; therefore we use labor income of the higher-earning spouse in our calculation if the lower-earning spouses contributed less than one third of household labor income.

We also include employee contributions towards defined contribution pension plans, calculated as the reported contribution rate on the current job times labor income. The PSID does not contain information on employer contributions.

Our measure of disposable income is the household real income after taxes. In the PSID, this variable is constructed as "the sum of total family income from labor earnings, asset flows, private transfers, private pensions, public transfers, and social security pensions minus total household taxes. Labor earnings include wages and salary from all employment including selfemployment (farming, business, market gardening, and roomers and boarders), professional practice or trade, and bonuses, overtime and commissions. Asset flows include income from interest, dividends, and rent. Private transfers include child support, alimony, and income 
from non-household members. Private pensions include retirement income from private pension plans, Veterans Administration pensions, and annuities. Public transfers include AFDC payments, supplemental security income (SSI), unemployment compensation, workers compensation, and the face value of food stamps. Social security pensions include social security payments received by the head, partner, and other family members. Total household taxes includes income taxes of the head, partner and other family members, as well as payroll taxes of the head and partner."

We calculate the saving rate by dividing active saving and the change in wealth by five or two times average disposable income, depending on the period under consideration. For each measure of saving we use the corresponding average disposable income measure. For the change in wealth, we add capital gains in housing, stocks and businesses to the measure of disposable income discussed above. For the change in wealth plus pensions and social capital, we also add the worker's contributions to social security and pension plans to disposable income.

As instruments we use:

a. Two measures of consumption: food consumption, and weighted consumption. Total real annual food consumption is the sum of total real annual food consumed at home (including the amount saved from food stamps) and annual real food consumed out of the home. To construct the measure of weighted consumption we use the weights from Bernheim, Skinner and Weinberg (2001) and we calculate consumption as C $=1.930$ (food at home $)+2.928$ (food away from home $)+1.828($ rental payments if renter $)+0.1374$ (value of house if home owner). Consumption measures are only available beginning in 1994, since food questions were temporarily suspended in 1988.

b. Education: This is measured as the number of years of education completed by the head of the household at the end of the saving period.

c. Average labor income: This is computed using all observations on labor income for the 
time period that a household remains in the sample. To compute this variable, we extend our sample to all the years available (1968-2007), and not only those years for which we have a wealth supplement. On average this measure includes fourteen observations of yearly income.

The sample selection is as follows: we exclude households whose head was less than 30 years old or older than 60 years old at the middle of the saving period. We select households with an absolute value of active saving not larger than $\$ 1,050,000$ and with disposable income of at least $\$ 1,400.17$ in a given year. From the remaining sample, we drop households in the extreme $0.5 \%$ of the distribution of saving. We also drop observations for households that had a change in head. We end up with a sample of 24,036 observations about 8,063 households, with a minimum of 2,815 households in any given year.

To test if our results could be driven by differences in redistribution across time or states we construct an index variable that indicates the political party of the state governor during the period in which the savings decision took place. This variable goes from 0 , the state governor was a Democrat during the entire period, to 1, the state governor was a Republican during the entire period. To test if our results could be driven by differences in variation in real estate prices we include state level housing prices in our standard specifications. For this we use the monthly S\&P/Case-Shiller Home Price index available on www.spindices.com. It tracks repeat sales of houses and are a modified version of the original method by Case, Shiller and Weiss.

In section 5, we use aggregate data for six different countries: Canada, France, Germany, Japan, the UK and the US. The sample consists of annual observations covering 1954-2007, except for Germany, for which the saving variable is measures at a tri-annual basis. The variables used are the following: 
a. Household saving rates. Obtained from different OECD yearbooks (1975, 1980, 1983, 1988, 1991 and 2001).

b. Inequality. Measured as the share of income received by the top $5 \%$ households. Source: Alvarado et al. (2012).

c. Age dependency ratio: measured as the population aged 65 and over as share of total population. Source: Groningen Growth and Development Centre Total Economy Database, http://www.rug.nl/research/ggdc/data/total-economy-database-.

d. GDP growth. Source: World Bank National Accounts.

e. The real interest rate is measured as the interest on bonds minus inflation. Source: Federal Reserve Bank of St. Louis (Federal Reserve Economic Data), series INTGSxxSM193N, where $\mathrm{xx}=\{U S, D E, J P, C A, G B, F R\}$, and $\mathrm{xxxCPIALLMINMEI,} \mathrm{where} \mathrm{xxx}=\{U S A, D E U$, $J P N, C A N, G B R, F R A\}$, available at http://research.stlouisfed.org/fred2.

f. Financial development: Stock market capitalization over GDP. Source: Beck and DemirgucKunt (2009) 


\section{Appendix I (for online publication)}

Finding the counterparts of (4), (5), (7), and (8) for the $i$-th household born in period $t$, where $\bar{g}_{t}^{i}$ and $\bar{o}_{t+1}^{i}$ are the levels of consumption of his reference group when young and old respectively, we obtain

$$
\begin{gathered}
s_{t}^{i}=\beta(1+\mu)\left[c_{t}^{i}-\gamma \bar{g}_{t}^{i}\right]+\frac{\gamma \bar{o}_{t+1}^{i}}{R} \\
c_{t}^{i}(1+(1+\mu) \beta)=y_{t}^{i}+\beta(1+\mu) \gamma \bar{g}_{t}^{i}-\frac{\gamma \bar{o}_{t+1}^{i}}{R} \\
d_{t+1}^{i}=\frac{1}{1+\mu}\left[R s_{t}^{i}+\mu \gamma \bar{o}_{t+1}^{i}\right] \\
b_{t+1}^{i}=\frac{\mu}{1+\mu}\left[R s_{t}^{i}-\gamma \bar{o}_{t+1}^{i}\right]
\end{gathered}
$$

We proceed sequentially. First we solve (23)-26) together with (18), noting that $\bar{c}_{t}^{H}=c_{t}^{H}$ and $\bar{d}_{t+1}^{H}=d_{t}^{H}$, to obtain the optimal choices of the rich households,

$$
\begin{gathered}
c_{t}^{H}=\pi y_{t}^{H} \\
s_{t}^{H}=\beta(1+(1-\gamma) \mu) \pi y_{t}^{H} \\
d_{t+1}^{H}=R \beta \pi y_{t}^{H} \\
b_{t+1}^{H}=(1-\gamma) \mu R \beta \pi y_{t}^{H}
\end{gathered}
$$

We now solve the corresponding system for poor individuals, noting that $\bar{c}_{t}^{L}=c_{t}^{L}$ and $\bar{d}_{t+1}^{L}=d_{t}^{L}$. From 25 we reach

$$
(1+\mu-\mu \gamma \rho) d_{t+1}^{L}=R s_{t}^{L}+\mu \gamma(1-\rho) d_{t+1}^{H}
$$

Using 23

$$
s_{t}^{L}=\beta(1+\mu)(1-\gamma \rho) c_{t}^{L}-\beta(1+\mu) \gamma(1-\rho) c_{t}^{H}+\frac{\gamma \rho}{R} d_{t+1}^{L}+\frac{\gamma(1-\rho)}{R} d_{t+1}^{H}
$$


Substitute 31 into 32

$$
\frac{(1+\mu)(1-\gamma \rho)}{1+\mu-\mu \gamma \rho} s_{t}^{L}-\beta(1+\mu)(1-\gamma \rho) c_{t}^{L}=-\gamma \beta(1+\mu)(1-\rho) c_{t}^{H}+\frac{\gamma(1-\rho)(1+\mu)}{R(1+\mu-\mu \gamma \rho)} d_{t+1}^{H}
$$

From 24 and (31),

$$
\frac{\gamma \rho}{1+\mu-\mu \gamma \rho} s_{t}^{L}+(1+\beta(1+\mu)(1-\gamma \rho)) c_{t}^{L}=y_{t}^{L}+\beta(1+\mu) \gamma(1-\rho) c_{t}^{H}-\frac{\gamma(1-\rho)(1+\mu)}{R(1+\mu-\mu \gamma \rho)} d_{t+1}^{H}
$$

Write 33 and (34) using 27) and (29) as

$$
A x=b
$$

where

$$
\begin{gathered}
A \equiv\left[\begin{array}{cc}
\frac{(1+\mu)(1-\gamma \rho)}{1+\mu-\mu \gamma \rho} & -\beta(1+\mu)(1-\gamma \rho) \\
\frac{\gamma \rho}{1+\mu-\mu \gamma \rho} & 1+\beta(1+\mu)(1-\gamma \rho)
\end{array}\right] \\
x \equiv\left[\begin{array}{c}
s_{t}^{L} \\
c_{t}^{L}
\end{array}\right] \\
b \equiv\left[\begin{array}{c}
-\beta \gamma(1+\mu)(1-\rho)\left(\frac{\mu(1-\gamma \rho)}{1+\mu-\mu \gamma \rho}\right) \pi y_{t}^{H} \\
y_{t}^{L}+\beta(1+\mu) \gamma(1-\rho)\left(\frac{\mu(1-\gamma \rho)}{1+\mu-\mu \gamma \rho}\right) \pi y_{t}^{H}
\end{array}\right]
\end{gathered}
$$

that applying Cramer's rule can be solved simultaneously for

$$
\begin{gathered}
s_{t}^{L}=\psi \beta\left[(1+\mu(1-\gamma \rho)) y_{t}^{L}-\mu \gamma(1-\rho) \pi y_{t}^{H}\right] \\
c_{t}^{L}=\psi\left(y_{t}^{L}+\gamma \mu \beta(1-\rho) \pi y_{t}^{H}\right)
\end{gathered}
$$

and then $d_{t+1}^{L}$ and $b_{t+1}^{L}$ are given by (31) and (26), respectively. 